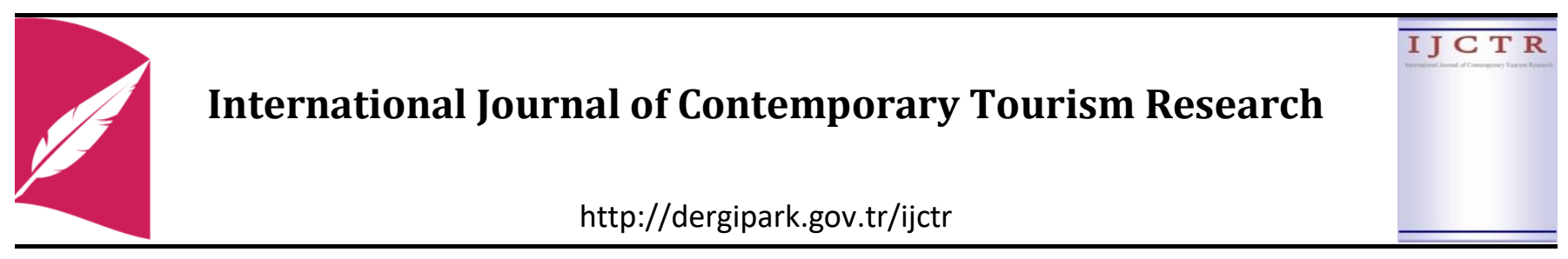

\title{
IDENTIFYING AND MAPPING OF HALAL TOURISM RESOURCES AND ROUTES IN ETHIOPIA
}

\section{Research Article}

\author{
Mohammed Jemal AHMED ${ }^{1}$, Atilla AKBABA ${ }^{2}$
}

\begin{abstract}
This paper discussed the availability and viability of halal sites and routes in Ethiopia. Tourism development requires detailed information about potential tourism resources. Accordingly, inventorying the existing actual and potential tourism resources should be the first step to assess the tourism potential of a certain destination. The main aims of this paper are twofold: to identify and discuss cultural and natural visitor attractions that will entice halal conscious visitors; and to propose halal tourism routes based on these resources. The proposed halal tourism routes lie down from the center, Addis Ababa towards different parts of Ethiopia. The study employed qualitative methodologies namely interviews, focus group discussion and field observations. GIS technology was also widely used to identify, locate visitor attractions and plot the spatial interconnection between these attractions. The findings of the study confirm that Ethiopia has abundant potential tourism resources to develop halal tourism. These resources mainly consist of Islamic heritage and natural resources. After the identification of the available tourism resources, five potential halal tourism routes were proposed.
\end{abstract}

Keywords: Halal Tourism, Halal Tourism Resources, Inventory, Routes

JEL Classification Code: Z32

\section{INTRODUCTION}

Tourism development requires detailed information about potential tourism resources that help developers and decision-makers. Inventorying the existing actual and potential tourism resources is expected to be the first step to assess the tourism potential of a destination. This paper, therefore, aims to identify, inventory, classify the actual and potential tourism resources in Ethiopia, and propose potential halal tourism routes that could be used as baseline data by decision-makers for future halal tourism development. Additionally, assessing potential attractions and proposing possible halal tourism routes will help to determine suitability and likelihood of success if development does take place. This paper also expected to answer the following questions: where are the visitor attraction that suit halal tourism development located? What are the suitable and feasible routes to access these attractions? Five clusters of visitor attractions were identified and accordingly five routes were proposed. The locations of major attractions were identified by GPS and GIS and mapped accordingly.

\footnotetext{
1 Ph.D., İzmir Kâtip Çelebi University, Graduate School of Social Sciences, Department of Tourism Management, mojem12@gmail.com, orcid.org/0000-0002-8744-7328; Principal inverstigator.

2 Prof. Dr., İzmir Kâtip Çelebi University, Faculty of Tourism, Department of Gastronomy and Culinary Arts, atilla.akbaba@ikc.edu.tr, orcid.org/0000-0002-9434-2145, Co-invenvestigator.
}

"Ahmed, M. J. \& Akbaba, A. (2021). Identifying and Mapping of Halal Tourism Resources and Routes in Ethiopia, International Journal of Contemporary Tourism Research, Vol 5: No: 1, p.13-34, doi: 10.30625/ijctr.831602" 
Moreover, the five tourism routes and their respective nodes were discussed and mapped.

\section{STUDY AREA}

The study was conducted in Ethiopia. Having about 115 million population, Ethiopia is the second populous country in Africa next to Nigeria. It is a horn African country divided into 10 regional states namely Tigray, Afar, Amhara, Oromia, Somali, Benshangul Gumuz, South Nation Nationalities and Peoples, Gambela, Harari and Sidama, and two federal city Administrations namely Addis Ababa and Dire Dawa.

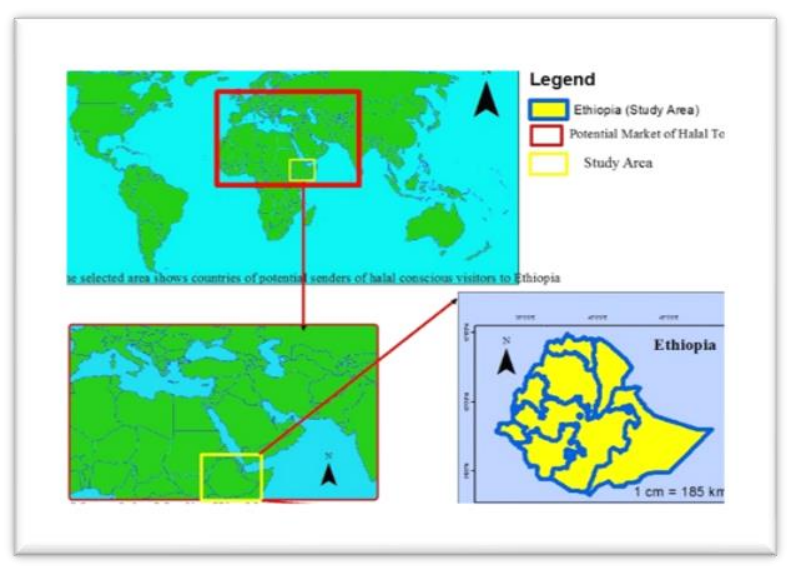

\section{Figure 1: Map of the Study Area Methodology METHODOLOGY}

The study employed qualitative methods namely interviews, focus group discussions and field observations. GIS technology was also used to identify, locate visitor attractions on a map, and plot the spatial interconnection between visitor attractions. Some data were extracted from maps of the study area when the respondents did not provide data. Archival and secondary sources have been consulted and crosschecked with personal observations and interviews. The main methods used for identifying halal tourism routes include participant observation, group discussion and unstructured in-depth interviews. Interviews were conducted with various stakeholders who represented route forums, route members, local government officials and non-governmental representatives. The initial step in a route's development is the approach made to stakeholders such as tour operators, government officers, nongovernmental organizations, tourism experts, GIS experts and community representatives. In addition to these, all interested parties were also welcomed and considered to add value. On this basis, routes have been proposed to embrace a wide cross-section of interests, in rural and farming communities, townships of metropolitan areas, as well as small towns and villages. The researchers offered stakeholders and participants the opportunity to propose possible halal routes and identify potential attractions that would lure halal conscious visitors. According to an interview held with tour operators, information on travel patterns of halal conscious visitors in Ethiopia is hardly available, and arrival and departure statistics for remote areas are virtually non-existent, which has made this research a particularly challenging task. It was luckiness that during the development of the halal tourism routes, indicators of halal tourism growth were available and this ease the task of determining the feasibility and viability of the routes.

\section{Inventory and Descriptions of Halal Visitor Attractions in Ethiopia}

This section will discuss the availability and viability of halal tourism resources and routes in Ethiopia. Tourism development requires detailed information about potential tourism resources. Accordingly, inventorying the existing actual and potential tourism resources must be the first step to assess the tourism potential of a destination. The main aim of this section is to identify and discuss cultural and natural visitor attractions that will entice halal conscious. Geographic Information System (GIS) and Geographic Positioning System (GPS) technology were also widely used to identify, locate visitor attractions and plot the spatial interconnection between these attractions. Inventorying the existing actual and potential tourism resources must be the first step to assess the tourism potential of a destination. Moreover, this section also expected to answer the following questions: where are the visitor attractions that suit halal tourism development located? What are the viable and feasible routes to access these attractions?

Attractions are the core elements in tourism development. Unfortunately, the unavailability of data and material has been challenging to research visitor attractions (Fyall et al., 2012). Inventorying and identifying the available visitor attractions are the main tasks in tourism development. Ethiopia, also called jewelry of the African continent (World Bank, 2006), is endowed with various natural, 
cultural and archaeological visitor attractions. This paper seeks to present halal visitor attractions of Ethiopia. The attractions were identified based on personal observation, FGD and interviews conducted with various stakeholders.

Indeed, halal conscious visitors might be interested in any attraction as far as that attraction is not in a position to transgress on sharia laws and/or halal services and ancillaries are available around that site. However, there are specific products that could specifically be preferred by halal conscious visitors. In the current study, the researchers tried to identify major attractions that probably fit with the interest of halal conscious visitors and have been marginalized by tourism developers. The actual and potential halal tourism resources in Ethiopia were identified and classified into five clusters, namely the North, Northeast, East, South East and Southwest based on geographical zone and location. These clusters include natural resources such as topography and landform, water, area's geological formation, natural beauty and flora. Tangible cultural resources such as archaeological sites, heritage buildings, handicraft products and intangible cultural heritages such as oral traditions, performing arts, social practices, rituals and festive events (Munzuma, Sufi Dances traditions, Islamic festivals such as Mawlid, Eid Al Fatir and Eid Al Adha).

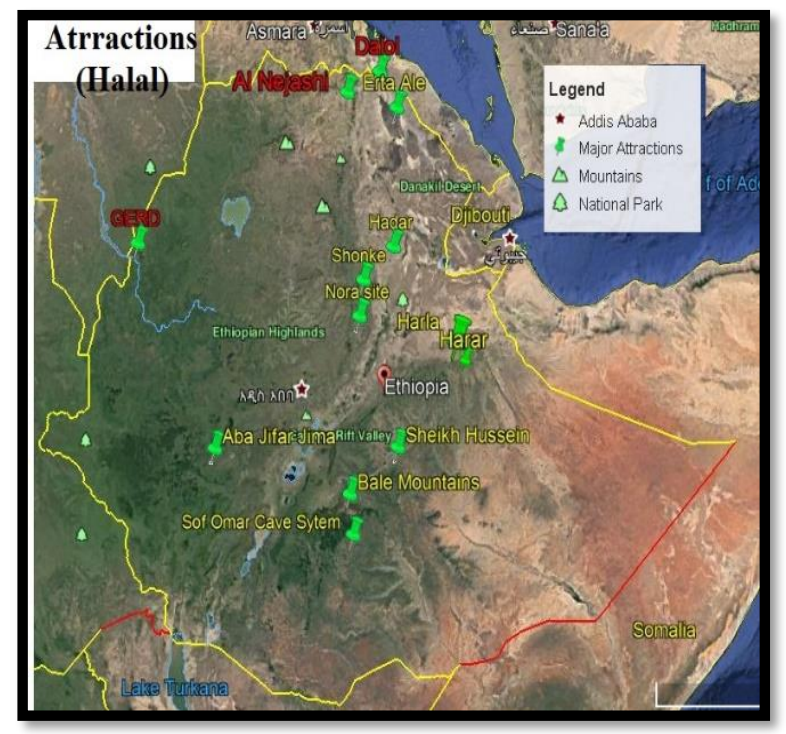

Figure 2: Distribution of Major Halal Attractions, by the Researcher THE NORTH CLUSTER

Islamic Archaeological Sites of North Showa
Ethiopia is the second country to accept Islam next to Saudi Arabia and is highly connected to Islamic history, heritage and identity (Erlich, 2009; Hussien, 2001; Trimingham, 1952). North Showa is among the historic areas of Ethiopia where Islam left its footprints (Khalaf \& Insoll, 2019). It is rich with Islamic archeological remnants including ruins of Islamic sultanates such as Showa and Ifat. Unfortunately, these beautiful visitor attractions are not promoted and introduced to visitors. Recently archeologists unveiled the ruins of Ifat sultanate towns. French archaeologists unearthed about three medieval towns of Ifat Sultanates, namely Asbari, Nora and Mesal in 2007 (Khalaf \& Insoll, 2019). The ruins of mosques and graveyards are discovered. Among others, the remnant of the great mosque of Nora is located at (Nora $09^{\circ} 50^{\prime} 52.81^{\prime \prime} \mathrm{N}$, $40^{\circ} 3^{\prime} 05.27^{\prime \prime}$ E) attracted the attention of archaeologists (Fauvelle-Aymar et al., 2006; Khalaf \& Insoll, 2019; Pradines, 2011)

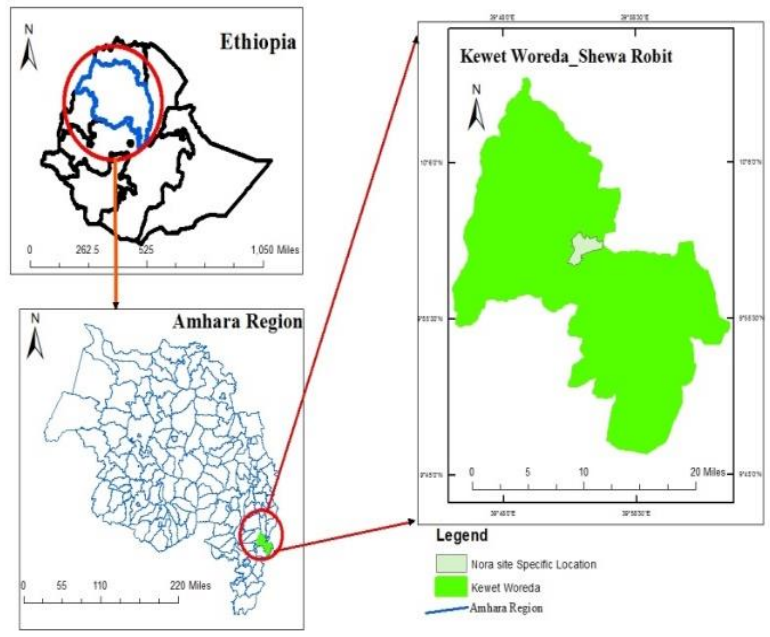

Figure 3: Location of Nora site: by the researcher

Nora site is found in Kewet Woreda of Northeast Showa in the town of Shewa Robit near the village of Wässiso about $300 \mathrm{~km}$ north of Addis Ababa (Fauvelle-Aymar et al., 2006). The ruins of the mosque reveal features of the medieval Islamic civilization of Ethiopia. Walls of 5 meters high surround the remnants of the city's main mosque (Fauvelle-Aymar et al., 2006). It is unprecedented that one door of the mosque built of wood has remained standing for centuries (Khalaf \& Insoll, 2019). As recent excavations indicate, Nora is believed to have been the ancient city of Muslims as old as Axum, Al- Nejashi. As noted by Khalaf and 
Insoll (2019) the abandoned Islamic town of Nora was the seat of the Ifat Kingdom. Archeologists have verified that Nora was a center of Red sea trade networks and had a relation to the northern Tigray as far as Dahlak Islands. Recently, archaeologists discover mosques, mausoleum, cemeteries and other heritages (Khalaf \& Insoll, 2019; Pradines, 2011). According to key informants, even there is a strong argument that the first Hijra of Muslims of the 615 was conducted towards Showa, not to Axum. The researcher interviewed an archeologist who works in the area at Addis Ababa University. He highlighted the potential of Nora archaeological sets for the development of halal tourism. He alleges that North Showa is rich in antique Islamic heritages and a hub of Islamic archaeological sites.

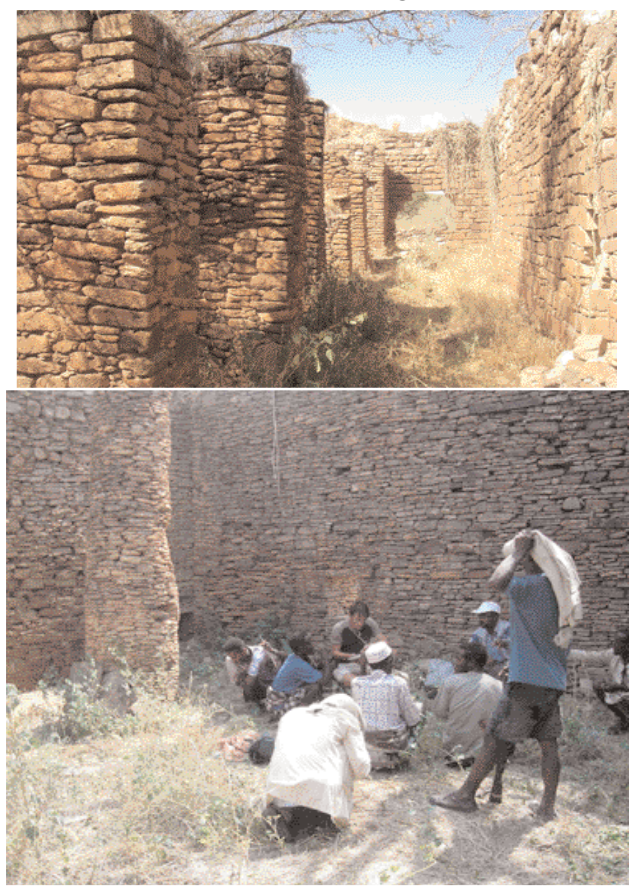

Figure 4: Ruins of ancient Mosques of Ifat Sultanate: Photo by French Research Team

In addition to interviews, a group discussion was held with tourism industry stakeholders to identify the potential of the area. The conclusion of the discussion reveals that in addition to the Nora Islamic archaeological site, there are also several Islamic heritages such as ancient education centers and Mosques. The discussants also allege the availability of ancient handwritten Islamic literature including secular and religious documents in mosques and the hand of individuals. This indigenous literature is believed to be another asset to attract halal conscious visitors and researchers.

\section{The Ancient Mosque and Residential Complex of Shonke}

The Wollo area is the hub of Islamic learning and the Islamic culture in Ethiopia. To denote its role as a center of Islamic education and research center, the local people called Wollo "Az'harul Habesha." Mainly it was from this area that Islamic education and culture spread towards different parts of Ethiopia. Nowadays, there are several ancient Islamic educations centers and Mosques in Wollo. Some of these heritages are still intact and active whereas the rests are available only with their remnants and ruins. There are also "literacy heritages" of old-aged manuscripts or Islamic literature, intangible heritage, and performing arts such as Islamic Menzuma and Neshida. As one participant speaks "[...] among the ancient religious sites and Sufi-order centers of Wollo, Shonke, Turusina, JamaNigus, Geta, Deger, and Debat are notable ones."

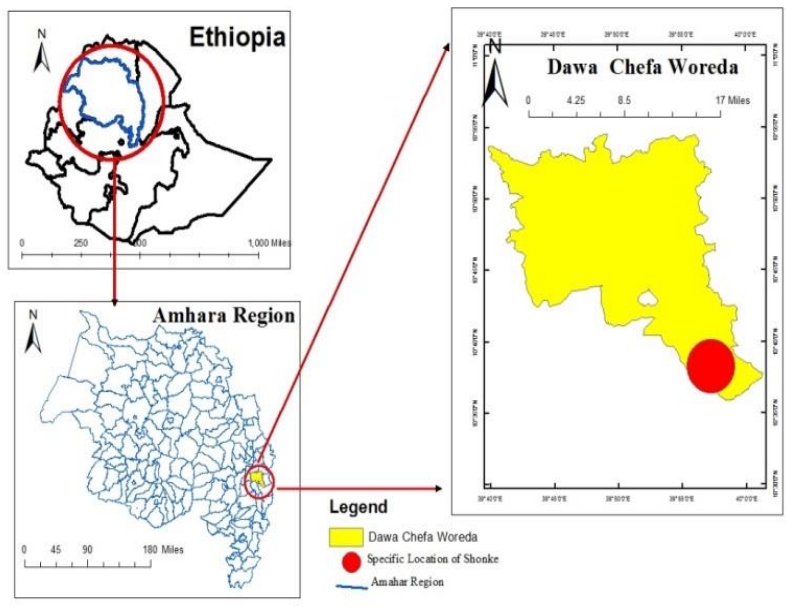

\section{Figure 5: Location of Shonke Site: Prepared by} the Researcher

Shonke is a historic village located $23 \mathrm{~km}$ away from Kemissie town, in Jirota kebele of the Amhara region. This site has been Islamic educations and Sufi-order centers where notable Sufi saint-scholars like Sheikh Jawhar Haydar Ali (1837-1937) permanently taught and produced many Muslim scholars (Ahmed, 2004; Eyassu et al., 2019). The village was flourished 900 years ago on the top of a plateau as a residential complex and an Islamic education center. The village has been serving for more than 20 generations (Eyassu et al., 2019). Agroba people constructed Shonke mosque and village nine hundred years ago (Eyassu et al., 2019). Argoba people are adherents of Islam and they have 
a tradition of construction of mosques and villages from Stone, wood and mud. It must be noted that the Argoba people also built Nora mosque (Ahmed, 2004). They have constructed the most known Shonke village and mosque in the 12th century. The ancient mosque and village of Shonke is built in a breathtaking mountainous area. Situated at the breathtaking views, historical and religious sites of Shonke consists of residential houses and mosques to draw the attentions' of visitors. According to local tour operators, the ancient villages and building heritages of Shonke is among the underutilized Islamic Heritages of Ethiopia.

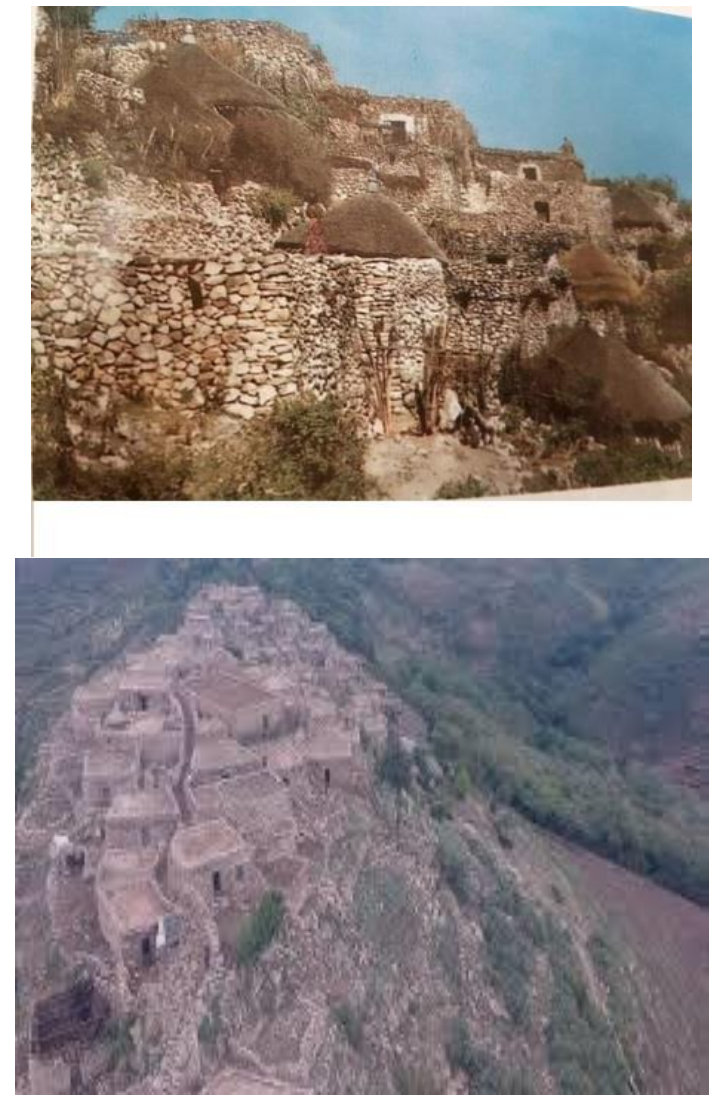

Figure 6: 900-years-old Shonke Villages and Mosque: Photo By Dawa Chefa Woreda Tourism Bureau

Tour operators and tourism experts allege that the area has a huge potential for halal tourism development. In addition to its location near the historic sites of the sultanate of Ifat, there are several Islamic heritages and Islamic archaeological sites around Shonke. Shonke will be among the major node of the proposed Al-Nejash Historic Route. To use it as an attraction for the halal conscious visitors, Shonke should be preserved and transmitted from generation to generation.

\section{Al-Nejash Religious and Historic sites}

Ethiopia is the first country in the world to welcome Islam in the early 7th century. The Prophet had his companions migrate to Habesha when they encountered brutalities and persecutions from the Quraysh of Mecca (Erlich, 1994). Therefore, Ethiopia is a holy country chosen by the Prophet Mohammed (PBUH) to save his companions. AlNejashi (As-ham), the then king of Habesha, gladly received the Sahabas and allow them to live peacefully. Consequently, the Prophet designated Ethiopia as the land of peace, and its king AlNejashi as an example of justice (Erlich, 1994, 2009).

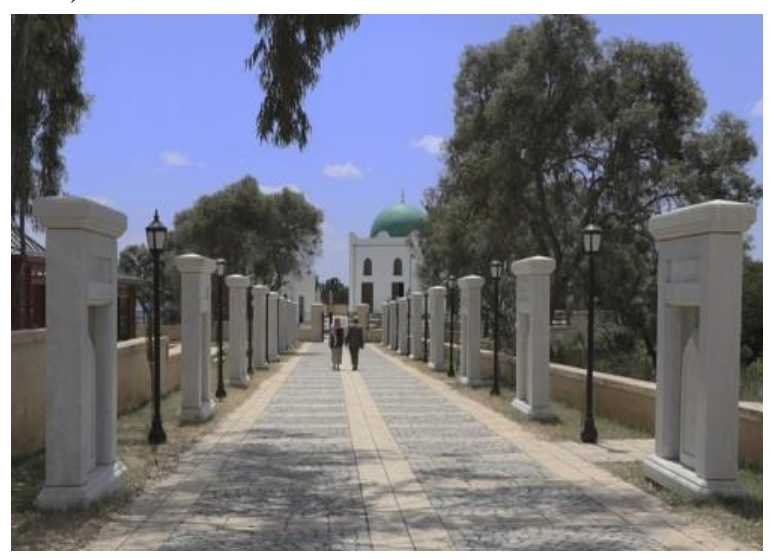

Figure 7: The mosque is also the site of the 15 tombs of the prophet's companions, Photo by Neima Adem (2018)

Al-Nejashi Site also called Negash Amedin Mesgid is found in the Tigray regional state of Wuqro town, 790 kilometers north of Addis Ababa. Al-Nejashi mosque is believed to have been the first mosque in Africa if not in the world. It is named after Nejashi, the Ethiopian king who welcomed companions of the Prophet Muhammed and ultimately converted to Islam (Erlich, 1994, Trimingham, 1952, Cerulli, 1971). Hence, Nejashi village is the place where the first Muslim settlement flourished in Africa. The Turkish Coordination and Cooperation Agency (TIKA) have recently renewed the mosque. The mosque was built on a historic place where 15 tombs of the prophet's companions are found. It is one of the most-visited religious sites by halal conscious visitors who are interested in Islamic history and culture.

A respondent from the federal Mejilis highlighted the role of Nejashi as follows: 
Al-Nejashi is not only playing a great role in Islamic history but also serves as an everlasting reminder of the warm welcome extended to the first Muslims by the Habesha king of the time. Therefore, it could be said that Nejash was the best diplomat, hospitable and the one who initiated halal tourism-like activity. It is denoted that Ethiopia is the first country to embrace Islam first prior to Africa and the world, and it is privileged to host halal tourism. Al-Nejashi mosque is, therefore, a historic and touristic place for anyone who wants to learn about the glorious history of the early Muslim civilizations.

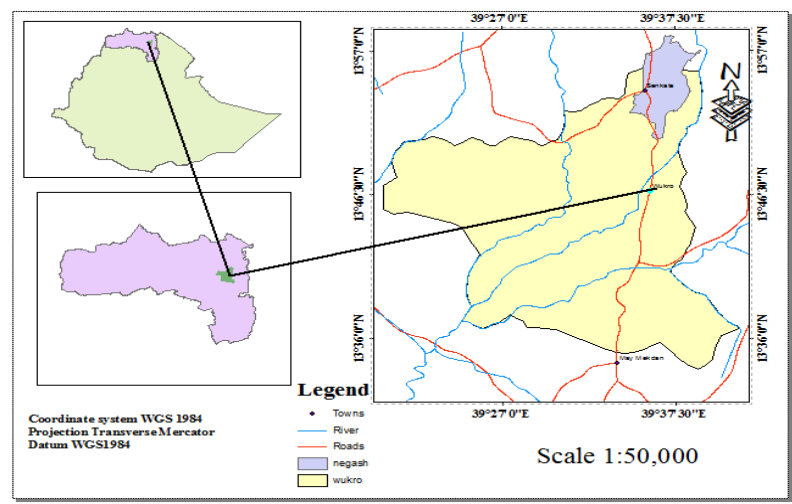

Figure 8: Location of Al- Najash Religious sites Attractions of Al-Nejashi Religious and Historic Sites

After having interviews with tourism officials, residents and visitors, sub attractions of Al-Nejashi religious and historic sites were identified and discussed as follows. Most of them are attracting domestic and international visitors to Al-Nejashi.

\section{The Story of the Sahabas}

The first attraction that lures halal conscious visitors is the story and the legend of the Sahabas (Companions of Prophet Mohammed). Most visitors prefer to visit Al-Nejashi to learn about the story of Sahaba who immigrated towards Axum Ethiopia during the era of Prophet Muhammad C. 615. As discussed earlier, hundreds of Sahabas were migrated towards Axum, Ethiopia. Most visitors are enthusiastic to hear about the story of those Sahabas from the local religious leaders by personally appearing in that historic site. As the Imam states, "in addition to the story the Sahabas both domestic and international visitors are interested to hear the story of King Al- Nejashi." King Al-Nejashi is believed to have been the first King in the world to embrace Islam. Therefore, he has an undeniable place in Islamic history and many
Muslims envisioned not only to visit his mosque but also to hear about his rich story. Therefore, histories, legends, and stories of the Sahaba and king Al-Nejashi served as sub attractions of AlNejashi religious and historic sites.

\section{Shrine and Mausoleums}

Shrine and Mausoleums were described as important attractions in the Nejashi religious site complex. As the Imam of Nejashi mosque cites, there are mausoleums of the Sahabas and King Nejash within the compound of Al-Najashi religious and historic sites. According to Neima, the mausoleum of King Al-Nejashi and 15 Sahabas (10 male and 5 female) were found in the compound (Niema, 2018). The pilgrims pay due attention to visit these tombs.

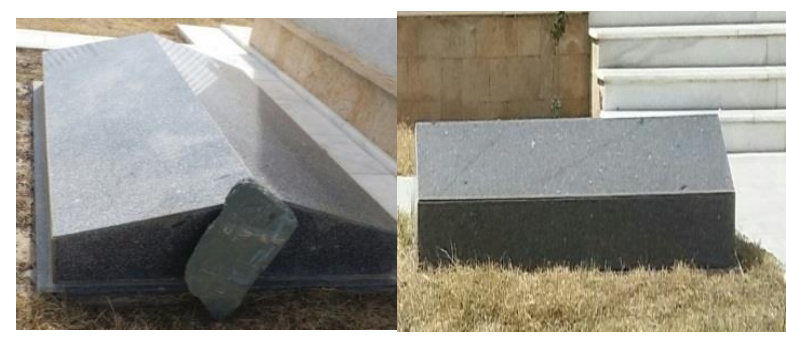

Figure 9: Tombs of Some Sahabas (Photo by the Neima Adem 2019)

As Niema (2018) states, the graveyards of the 12 Sahabas and King Negashi were found in the mausoleum. The rest three Sahabas namely, Udey bin Nedila, Abdela bin Al Haris (Sherif Abdilah), and Musa Bin Al Haris found outside of the Shrine and Mausoleums.

\section{Ashura Ceremony in Al-Nejashi}

As the root word of 'Ashura' "Ashir" indicates, Ashura is the 10th of Muharram, the first month in the Islamic or lunar calendar. Ashura is celebrated by some Muslims. For instance, according to key informants (religious leaders), Ashura is celebrated in Harar and at Al-Nejashi Wukro. According to one religious leader, many visitors visited Al-Nejashi during the festivity of Ashura. Both domestic and international visitors visited Al-Nejash during Ashura. For instance, there were visitors from Sudan and Eritrea during Ashura and domestic visitors travel to Al-Nejashi Wukro from all corners of Ethiopia to celebrate Ashura there, at Al-Nejashi. During Ashura, there are various performing arts such as colorful religious songs and dances. There are also souvenirs offered for visitors. 


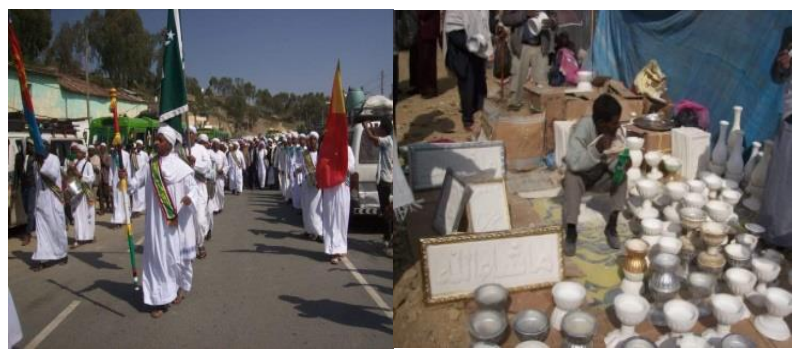

Figure 10: Photo of Ashura Ceremony (Photo by Niema, 2019)

Remnants of the First Al-Nejashi Mosque and Sahaba Houses build by the Suhabas themselves are other important attractions.

The Imam of the mosque explains the history of AlNejashi mosque as follows:

The first Mosque of al-Nejashi is different from the modern Al-Nejashi Mosque. These days we found only ruins of AlNejashi Mosque. There is a misunderstanding among the visitor and media personnel to differentiate between the Al-Nejashi mosque and Al-Nejashi cemetery. Most of the time the visitors visit the Al-Nejashi cemetery, but they assume it as the Mosque. Al-Nejashi cemetery was constructed during the time of Sahabas, in the 7 th century.

\section{The Northwest Cluster}

Northeast Ethiopia mainly the Afar region is rich in geological, geomorphological, and archaeological visitor attractions. This region possesses a huge potential to develop geotourism in Ethiopia. Afar region is internationally known for its geological formation such as Erta Ale and archaeological sites such as Hadar (Cavalazzi et al., 2019; Cieśluk et al., 2014). The area is widely visited by geologists and archaeologists. Therefore, the Afar region has a great asset to flourish halal tourism in Ethiopia. Afar holds an important place in the East African Rift System (EARS). Passing through Ethiopia, Kenya, Uganda, and Tanzania, EARS is one of the geologic formations wonders of the world. The Afar Triangle is a triple junction zone where the Red Sea, the Gulf of Aden and Ethiopian rifts intersect at the central Afar depression. Located in the system of the East African Rift valley, the Danakil depression is one of the lowest and hottest places on earth. Afar regional state of Ethiopia is rich in both archaeological sites and unique natural resources such as active volcanoes. Having archaeological sites and active volcanos, Afar is one of the beautiful landscapes to visit (Cieśluk et al., 2014). Though its temperature reaches up to $50 \%$ and seems inhospitable place, the Danakil depression is still interesting and worth visiting. Since 100 years, the Afar Areas are known for active volcanic and tectonic activities (Cavalazzi et al., 2019; Cieśluk et al., 2014)

\section{Dallol}

Located in the northern part of the Triangle (Danakil Depression) in Northern Ethiopia at the EthioEritrea border, Dallol Volcano is an important visitor attraction (Cavalazzi et al., 2019; Cieśluk et al., 2014). With an elevation of about $130 \mathrm{~m}$ below sea level, it is one of the hottest places throughout the year on the planet. Due to the extremely low elevation, Dallol becomes one of the hottest places inhabited location on Earth (Cavalazzi et al., 2019). Though not famous as that of Erta Ale, Dallol is also an active volcano located in the lowest place. It is believed that the landscape of the Afar depression was cut off from the sea; and over time, the Danakil Depression has lost its water because of desert evaporation. Dallol is found in the depression of 126 meters below sea level. Lied 118 meters below sea level, there is also a salty lake of Afrera (Cieśluk et al., 2014).

\section{Erta Ale}

The term Erta Ale is derived from the Afar language to mean, "Smoking Mountain" (Cieśluk et al., 2014.) Erta Ale is an active volcano found between Dalol and Afrera more than 100 meters below sea level (Cieśluk et al., 2014).

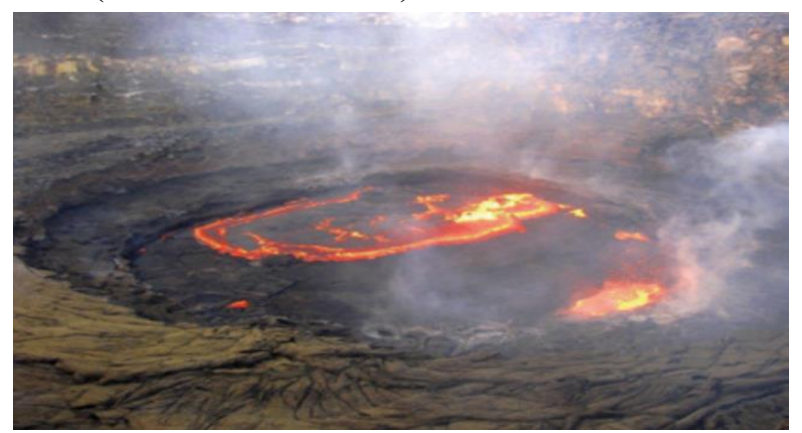

Figure 11: Lava Lake in Volcano Erta Ale crater, photo Z. Preisner, 2014

In the Afar Triangle, there are about 34 volcanoes. Of them, five are active and Erta Ale is the biggest one. Erta Ale is a rarely found volcano for it is liquid lava in its crater. As Cieśluk et al. (2014) state, Erta 
Ale remains active, for at least 100 years and it is the most visited volcano in the Afar region.

\section{The Hadar Archaeological Site}

Not only known by active volcanoes, but also the Afar region is a hub of archaeological sites where the oldest and the famous archaeological finding Australopithecus remain of Lucy was discovered. Afar has diverse archaeological and paleontological heritage resources. Hadar is the known archaeological sites of the Lower Awash of Ethiopia. It is one of the most prolific hominid archaeological sites in the world. During the survey conducted in the 1970s, about 240 specimens of hominid were unearthed and today about 400 specimens of Australopithecus Afarnes were uncovered in Afar (Cieśluk et al., 2014). Of them, Lucy was the most famous one. The Hadar archaeological site is located in the Afar depression, in the west-central Afar Triangle about $300 \mathrm{~km}$

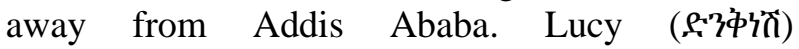
(Australopithecus Afarnes) is an almost complete skeleton of the first primitive man, which was estimated at 3.2 million years. Lucy was discovered in 1974 at Hadar, a site in the Awash Valley of the Afar Triangle in Ethiopia, by paleoanthropologist Donald Johanson (Cieśluk et al., 2014).

\section{The Eastern Cluster Attractions}

\section{The Ancient Walled City of Harar}

Harar is a walled historic city of Eastern Ethiopia. Located five hundred kilometers east of Addis Ababa, it is serving as the capital city of the Harari region (Bank, 2006). Harar is believed to have been the seat of the Islamic Kingdom of Adal (Insoll, 2017). It was established between the in seventh century (Ahmed, 2015). Harar is known to be the fourth holiest city of Islam in the world. It has been serving as a center of Islamic education and learning.

Harar was a base of Imam Ahmed Ibrahim who defeated the Christian kingdom of the north and ruled Ethiopia for a decade and a half (1527-1543). His successor Emir Nur Mujahid constructed the wall of Harar that encircled the historic city. The wall is 4 meters high and has five gates (Ahmed, 2015). The wall that surrounded the historic city is called the "Jugol Wall", which is still intact as a symbol of Harar city.

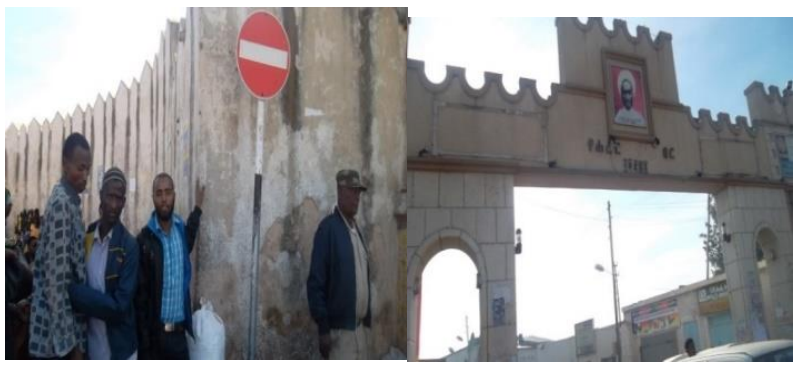

Figure 12: The Jugol Wall of Harar \& Its Main Gate: Photo data by collector

One participant from Harari culture and tourism Bureau alleges,

[...] Harar city has been known for its values of coexistence of multiple religions and cultures and for its historic wall of Jugol. Furthermore, Harar comprises a variety of cultural and historical attractions. Having such multiple attractions together, Harar city is referred to as an "Open Museum" of the east.

As proved by personal observation of the researcher, in Harar, there is a tradition of "Hyena Feeding Ceremony" every evening that attracts a considerable number of visitors. According to a local guide, a long-standing tradition of feeding meat to hyena evolved during the 1960s into an impressive night show for visitors. According to tour guides, there are more than three spotted hyenafeeding sites on the outskirt of Harar city.

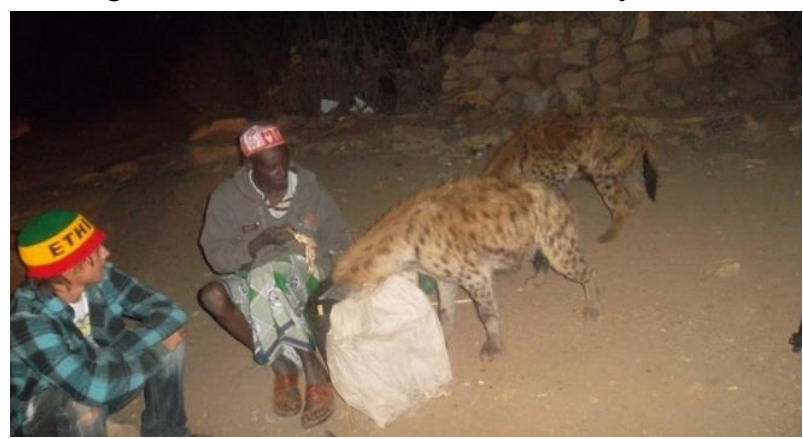

Figure 13: Hyena feeding man in Harar: Photo by the Researcher

In addition to being a mosaic per se, Harar city comprises four Museums that display the past and the living heritages of the peoples. Tour operators often promote Harar as "an open museum" to refer to Harar as a cultural mosaic that emerges not only various cultures and traditions but also it connects the traditions with modern practices (Asante, 2009). 
These Museums are Harar Regional Museum, Rimbaud's Heritage Building and Museum, Ada Gar (Harari Culture House) and Sherif Private Museum.

The curators of these museums in Harar were interviewed. They have highlighted the role of these Museums for Halal Tourism development. One curator alleges:

[...] most of the collections in our museum reflect the past civilization of the Harari, Somali, Oromo and other peoples in general, mainly traditional Harari architecture and material culture in particular. The Harari culture is a duplication of Muslim culture. Hence, these collections attract Muslim visitors who are mainly halal conscious visitors. In this Museum, one can observe the ancient civilization, culture and history of Islam and Muslims. For instance, one can see ancient coins, antique Arabic literature and the lists of Amirs that ruled Harar city from the 11th Century until the 19th Century. Hence, the Museums of Harar are important attractions for Muslim visitors who are mainly enthusiastic to visit Islamic history and culture $[\ldots]$.

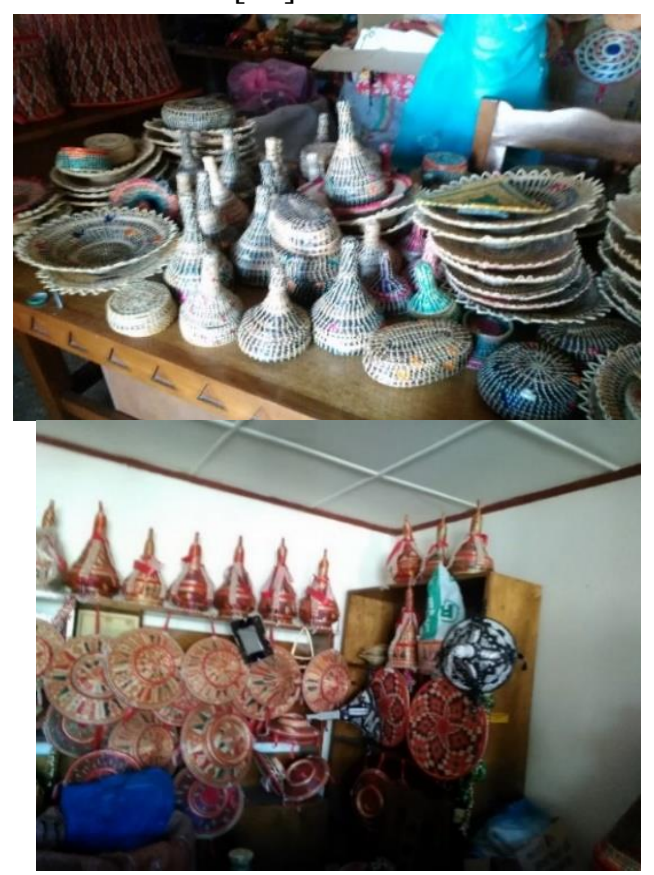

Figure 14: Colorful basket collections at Harar Museums, Photo by The researcher
Ada Gar is a museum where visitors enjoy viewing the architecture and house design of the Harari people. The building itself is designed in a way that reflects the internal architecture and house design of the Harari people. Of the four Museums, Rimbaud's Museum was established recently in the Heritage buildings of Rimbaud. Until he departed from Harar city in 1891, French poet Arthur Rimbaud used to live at Rimbaud's Building. The Museum is called Rimbaud after his name. In 2000, the house was transformed into a museum (Asante, 2009).

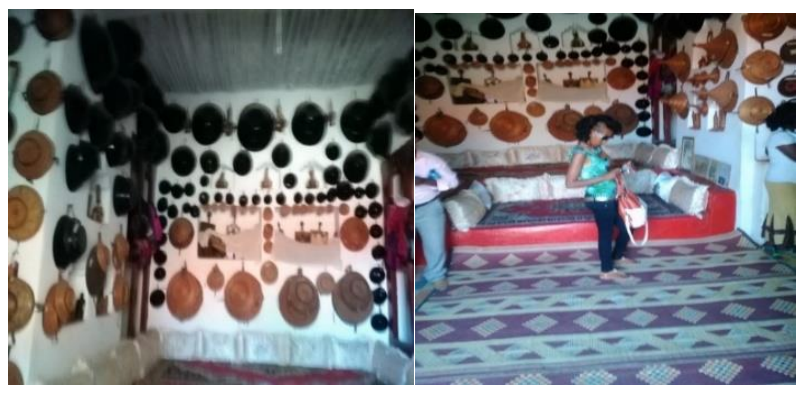

Figure 15: Basketry and wooden bowls cover the walls of Ada Gar museum, Photo, by the Researcher

\section{Basketry and Handicraft Products}

Although there are problems in production and marketing, handicraft products in the historic city of Harar is another cultural attraction. During the discussion regarding the handcraft of Harar city, one participant speaks the following: "the handicraft center is a strong point to showcase local traditional products and culture. Women from different parts of Ethiopia have taken basketry training." Other women alleges that numerous problems regarding the utility of the handicraft village by the local tourism officer. "The tourism industry players of Harar city do not fully understand what tourism product and visitor attractions are. They do not consider these beautiful handcrafts as visitor attractions. They don't know how to sell or promote the products of Harar city." During the field trip for data collection, the researcher personally has observed beautiful basket products of different forms. He has seen women from different parts of Ethiopia taking basket-making training. Besides being and becoming a visitor attraction, these handicrafts products could be offered for visitors as souvenirs.

\section{Heritage Buildings}

The existence of unique medieval period buildings is another important element of cultural and heritage 
attractions in Harar city. Most of the interviewees believe that these buildings could be used for halal tourism development. A tourism officer alleges the following:

[...] the walled city of Harar has old heritage buildings that would contribute to the development of halal tourism. Most of the buildings of the walled city of Harar such as mosques were the medieval period buildings that reflect the Islamic architecture of the medieval period so that they could be preferred by halal-conscious visitors.

A local officer claims:

Heritage buildings including about 80 mosques and other ancient buildings located within the walled city of Harar have been registered as world heritage and most of these heritage buildings reflect the Islamic civilization of Harar. Therefore, these could be assets for halal tourism development in the country.

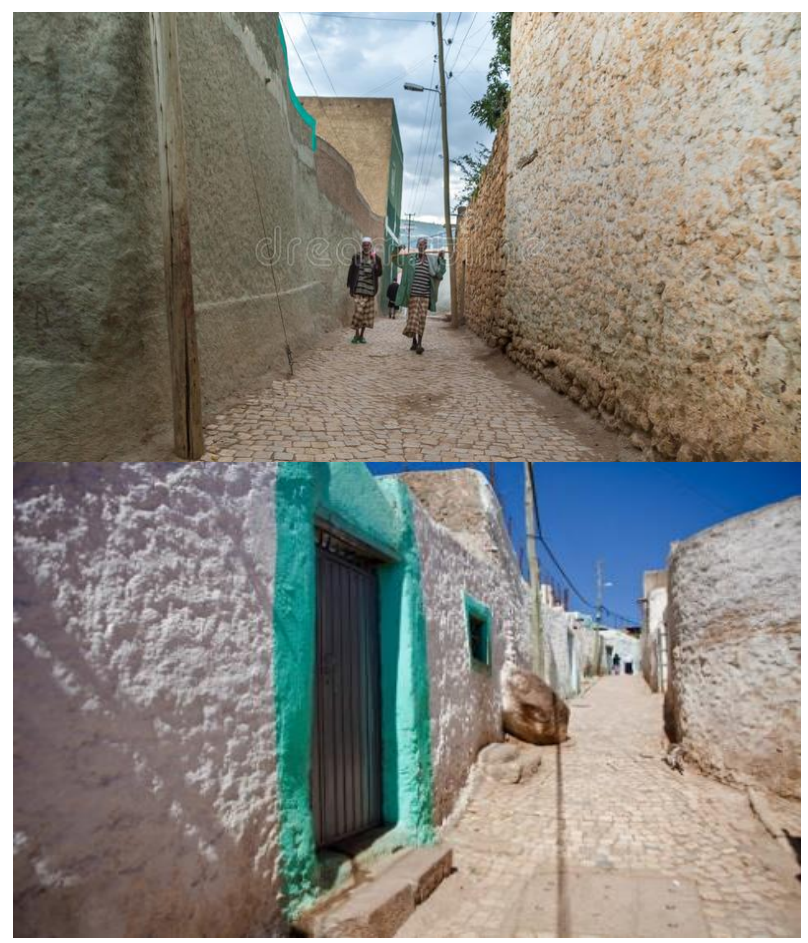

Figure 16: Heritages Building within the walled city of Harar: Photo by the Researcher

\section{The Abandoned Islamic City of Harlaa}

Harlaa, an abandoned Islamic city, is a signal of Islamic civilization in East Africa. It is located between Harar city and Dire Dawa City Administration (see Eastern Route below). Harlaa served as the capital city of Muslim sultanates. Nowadays, archaeologists unearth mosques and other Islamic heritage at Harlaa archaeological sites (Insoll et al., 2017).

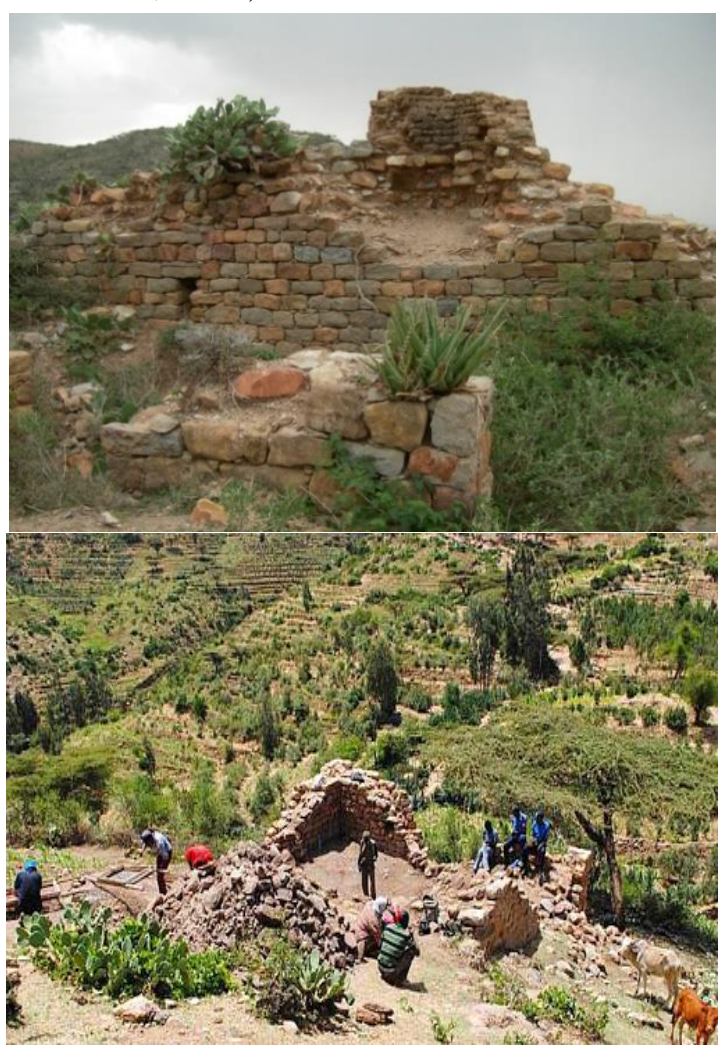

Figure 17: Archaeological Sites of Harlaa, Photo by Khalaf and Insoll, 2019

Recently they found a $12^{\text {th }}$-century mosque that is similar to those found in Tanzania and Somaliland. This shows the linkage of Ethiopian Muslim civilization with other African fellows. In addition to ruins of mosques and other Islamic heritages, archaeologists unveiled artifacts of Egypt, India and China (Khalaf \& Insoll, 2019). This proves that in addition to being the capital city of Islamic kingdoms, Harlaa was a cosmopolitan city where multicultural societies living together. The discovery of jewelry and other artifacts of Madagascar, the Maldives, Yemen and China proved that Harlaa was a center of trade (Insoll, 2017). Archaeologist Prof Insoll has proved that foreigners also used to live in Harlaa city and trade 
exchanges were conducted as far as Arabian Gulf, Red Sea and the Indian Ocean. There is also an unprecedented and unguessed thing that huge stoneblocks that cannot be normally lifted by people's power were used in construction (Insoll et al., 2017; Khalaf \& Insoll, 2019).

\section{The Daketa Rocks in Babile}

The Daketa rocks are found $5 \mathrm{~km}$ away from the tiny town of Babile, $40 \mathrm{~km}$ far from the ancient city of Harar and $560 \mathrm{~km}$ from the capital city of the country-Addis Ababa (Ahmed, 2012). The majority of the rocks here are extremely endowed with unique natural fascinations. Astonishingly, it is common to come across unique one over another overlapped rocks within a few intervals. The number of rock positioned one over the head of another rock sometimes going up to two to three. It seems just like great technological results have been applied in arranging the rocks like that. Together with the great scenic beauty of the landscape, the Daketa rocks serve as major natural attraction in Babile Woreda. As the researcher's observation and word of mouth of residents, there are also white baboons and various reptiles at Daketa rocks.
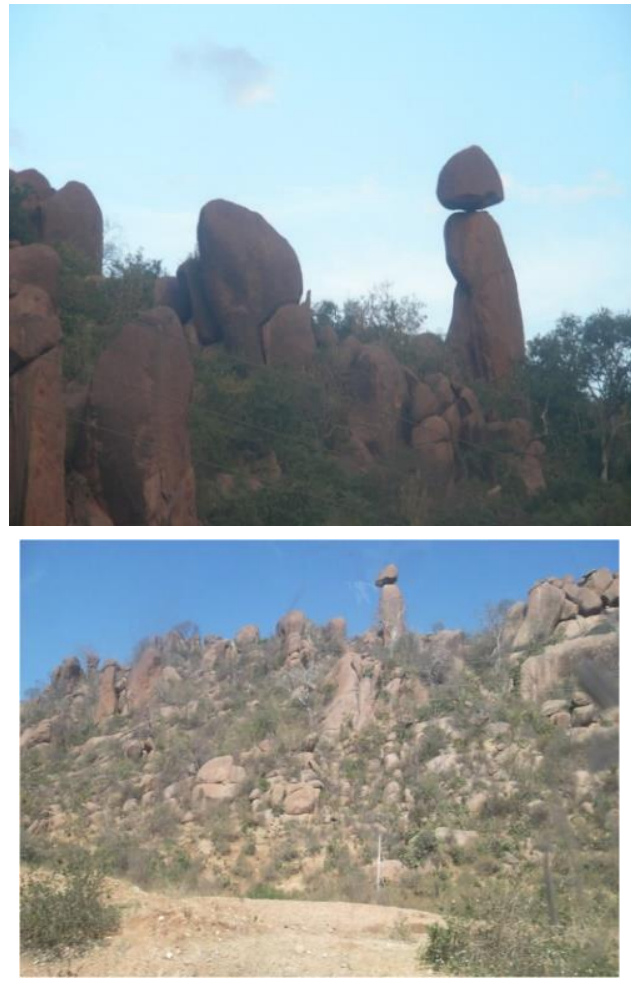

Figure 18: The Daketa Rocks in Babile: Photo by the Researcher

\section{Prison House of Lij Eyasu on the Gara Mulleta Mountains}

The prison house of Lij Iyasu is found $581 \mathrm{~km}$ far away east of Addis Ababa and $76 \mathrm{~km}$ west of Harar. According to an unpublished source of Eastern Harerge Zonal department for culture and information bureau, Yemeni architect by the order of Haile Selassie I built the prison house of Lij Iyau in 1931. As the name indicates, it was a prison where an Ethiopian king called Iyasu Michael (Iyasu Mohammed Ali before he ascended to power), who ruled the country from 1913-1916, was detained (Ahmed, 2012). He was imprisoned after the political intrigue between the Shoan Nobilities to which Haile Selassie I belonged and the Wollo local rulers from which Iyasu had his origin and Haile Selassie had overthrown him. Therefore, this prison represents one of the historical sites of Eastern Ethiopia as well as the country. Besides the historical value, the architecture of the prison and the scenic landscape of the Gara Mulata Mountain other supplementary visitor attractions of the area.

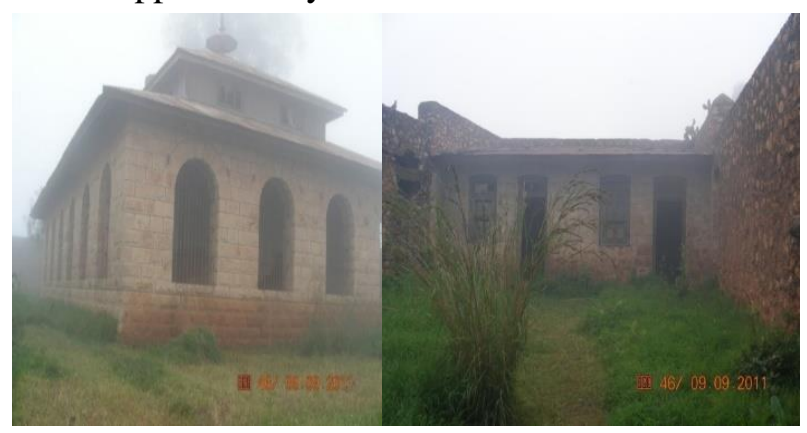

Figure 19: The prison House of Lij Iyasu: Photo by From Eastern Harerghe Zone Culture \& Tourism Bureau

\section{The Living Heritage and Traditional Cottage of Pastoralists}

Besides its other cultural and natural attractions, eastern Ethiopia comprises unspoiled and original live cultural attractions. According to one international visitor whom the researcher has interviewed in Harar, the visitors traveling at Daketa valley will enjoy not only by viewing the unique rocks of the area but also by watching and appreciating the very traditional cottage of the local pastoral communities, their camel and their way of life and their unspoiled culture as well. Therefore, the living style of pastoralist and their traditional cottage would become supplementary attractions for Daketa rocks. 


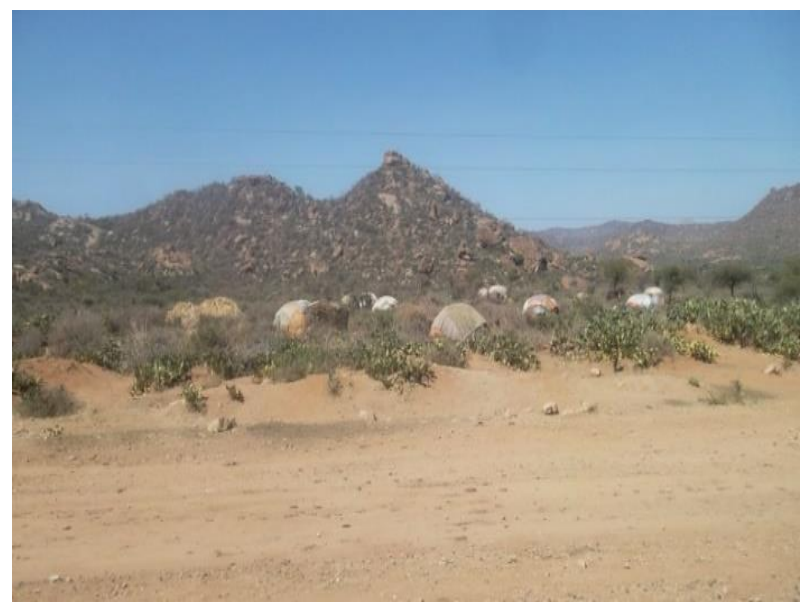

Figure 20: Traditional pastoralists Cottage in Babile, Photo by the Researcher

Southeast Cluster: Halal Tourism Resources of Bale Zone

Bale is located $430 \mathrm{~km}$ away from Addis Ababa in southeastern Ethiopia of Oromia Regional State. This area is endowed with diversified tourism resources of natural, anthropogenic and manmade attractions. Local communities, tourism experts from culture and tourism offices of Bale Zone and woredas, tour guides and visitors were interviewed to identify halal tourism resources in the area. Bale has three major attractions that could attract halalconscious visitors namely the Bale Mountains National Park, Sof Omar Cave System and Dire Sheik Hussein historical and religious sites.

\section{Bale Mountains National Park (BMNP)}

Bale Mountains National Park (BMNP) is a semideveloped visitor destination. In addition to being the largest African Afro Alpine Habitat Park, the park sheltered several endemic animals. According to the local guide, visitors to BMNP could enjoy watching over 46 mammals and more than 200 bird species and vegetation of an unspoiled wonderland. The park consists of endemic mammals such as the Ethiopian wolf, Bale Monkey, Mountain Nyala, and Menelik's Bushbuck (Aynalem et al., 2015). The park is located $400 \mathrm{~km}$ southeast of Addis Ababa and covers an area of 2000km2 (Bayih \& Tola, 2017). Both interviewees and focus group discussants confirm that Bale Mountains National Park is the most preferable attraction for halal conscious visitors. The religious leader also alleges that Islam encourages visiting natural attractions to admire what Allah creates.

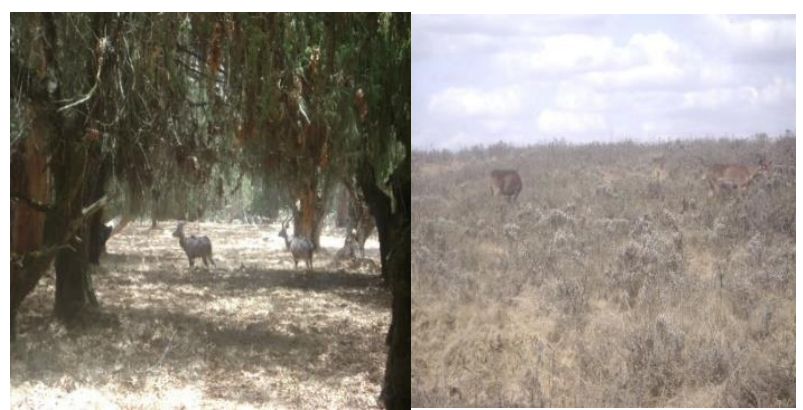

Figure 21: Wildlife at Bale Mountain National Park, Photo by the researcher

\section{Religious and Historical sites of Dire Sheikh Hussein}

Located $620 \mathrm{~km}$ southeast of Addis Ababa in Oromia, Ethiopia, Dire Sheikh Hussein is an important historical and cultural heritage of the Bale area. It is one of the oldest surviving Islamic education and cultural center in Ethiopia. The history of the site traced back to the late 12th C (Semu, 2016). A holy man named Sheikh Nur Hussein Melka founded the shrine 900 years ago (Tola, 2009).

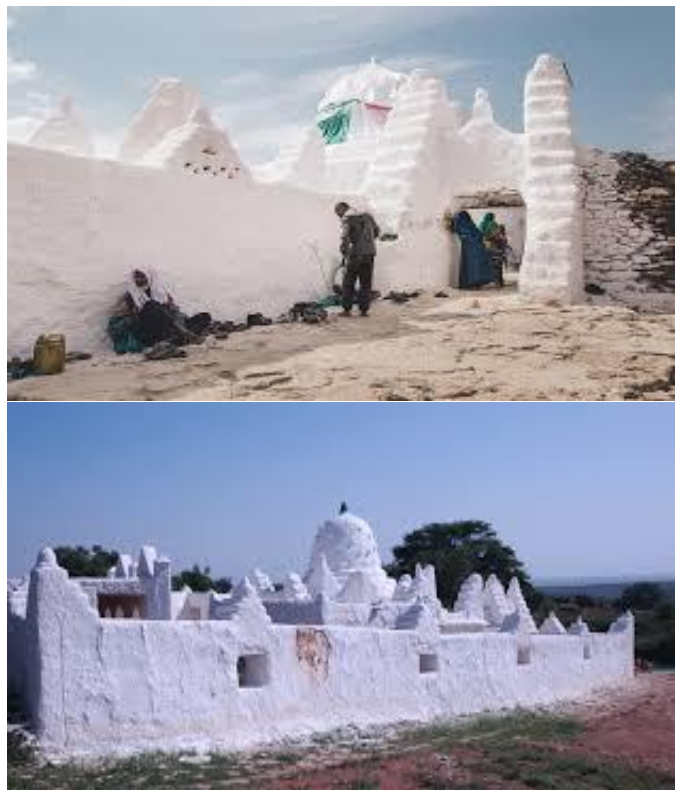

Figure 22: Building Heritages of Dire Sheik Hussein: Photo by Oromia Culture and Tourism Bureau

The Shrine is named after this popular religious teacher and leader. The term Dire is derived from Afan Oromo words, it means a plain. According to the local elders, he has known for his high devotion and miraculous deeds. He was born 950 years ago from his father Melka or Sheik Ibrahim and his mother Shamsiyya (Semu, 2016). According to 
legend, Sheikh Hussein lived for 250 years on earth and he devoted most of these years to praying and dhikr. According to key informants, he is said to have a blood relation with Prophet Mohammed and is credited for Islamizing Bale and its environs. Sheik Hussein is one of the most respected figures among Sufi Muslims. Sufi Muslims throughout Ethiopia venerate Sheikh Nur Hussein as a saint, spiritual leader and Holy man. As noted by respondents [of Sufi religious leaders], the Dire Sheikh Hussein shrine is one of the most visited sites by local pilgrims. People mainly Sufi Muslims make pilgrimages towards Dire Sheik Hussein to seek good health, fertility, material well-being and remedy for all their difficulties. The site of Dire Sheik Hussein shrines consists of magnificent groups of building heritages and courts representing the early medieval period of Islamic civilization, mausoleum architecture, historic settlement and beautiful landscape. The site is a huge countryside religious walled settlement portraying the living culture of the past that continue for nearly 1000 years.

According to respondents, people make a pilgrimage to Dire Sheikh Hussein twice a year. The major pilgrimage is carried out during the festival of Sheikh Hussein's birthday, mainly fixed in the first week of August. The second one is during the feast of Id al-Kabir, the great feast at the end of the Zul Hija (Semu, 2016). This one is the month of the pilgrimage to Mecca and the last month of the Islamic calendar. Key informant (Sufi-Muslim) alleges, "The poor people who cannot afford the pilgrimage to Mecca, the pilgrimage to Sheikh Hussein could substitute it." According to participants, Sufi Muslims consider Dire Sheik Hussein as "the little Mecca" for Ethiopian Muslims, as Lalibela is considered as "the Little Jerusalem" for the Ethiopian Christian community (Semu, 2016).

The living heritage and religious performance arts are the main practice of pilgrims. Visitors across ethnic and political boundaries sometimes across religious boundaries enjoy the festivals, melodious religious songs and dances. Pilgrims and local visitors allege, "The building of the site is aesthetically and architecturally attractive." Dire Sheikh Hussein's site also has comparative location advantages over other similar sites. Located between the peaks and the plains, in the eastern foothill of the Bale Mountains range and the Sof Omar Cave System, Dire Sheikh Hussein can add value to the experience of the visitors (Participants, 2019).

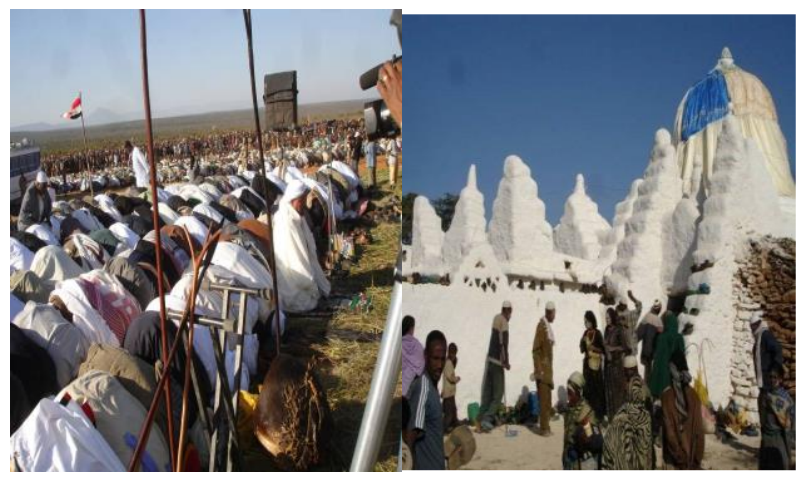

Figure 23: Local People on Pilgrimage at Dire Sheik Hussein, Source: Oromia Culture and tourism bureau)

\section{The Sof Omar Cave System}

The Sof Omar cave system also is known as Holqa Sof Omar is one of the most spectacular and the longest underground cavern in Africa (Aynalem et al., 2015). Sof Omar Cave is a giant underground cave formed by the cavernous Weib River that passes through limestone foothills. The Sof Omar cave system is a mixture of cultural heritages where Sheik Sof Omar used to within it for many years and an extraordinary natural phenomenon of breathtaking beauty and amazing geological formation (Aynalem et al., 2015). The cave is not only a natural heritage but also it is an important Islamic shrine named after the saintly Sheik Sof Omar Ahmed who used to pray there in the early 11 th century AD. Sof Omar is claimed to have been the favorite disciple and a close relative of Sheik Hussein. He was the most celebrated spiritual father of Sufi Muslims next to Sheikh Hussein (Participants, 2019). Therefore, the cave has a religious history that predates the arrival of the Muslims into Bale.

Sof Omar Cave System has a 16km length and about 40 entrances and exits. To travel throughout the cave system, the travelers advised having hand light because the inside part of the cavern is too dark. The researcher has traveled through the cave and proved that the inside part of the cave is very dark and it crosses the Weib River many times. The researcher has also seen a marvel of architecture and pillars of stone, and a flock of bats. According to local tour operators and elders, the cavern has different parts 
based on what was used by Sheik Sof Omar. There are parts of the cavern that was used for prayer and living room; there are rooms that were used as a court where justice is given and criminals were jailed. In addition to being a well-preserved sacred place of worship, Sof Omar cave has an indirect role in protecting the environment. It causes for the preservation of indigenous forest and natural habitat of the wildlife resources. Around this historic cave, one finds wild animals such as ape, monkey, tortoises, snakes and lizards as well as more than a hundred species of birds (Researcher Personal Observation).

The Cavern of Sof Omar is an exceptional geological process of limestone landforms and the most significant geological and geomorphological formations.

A local government official said:

Registered in the tentative list of UNESCO, the cave has outstanding universal natural heritage values. For instance, on the one side, the Sof Omar cave system contains unique geological and geomorphological formations or areas of exceptional natural beauty and natural aesthetic significance. The outstanding cultural landscape reveals incomparable geological and natural phenomena. This might aspire geologists and archaeologists to study the story of the cave systems formation over hundreds of millions of years and helps unlock the story of in-cave dwelling. On the other side, a cavern is a sacred place for Sufi Muslims and it has a role as an important cultural heritage. The cave is a palace where saint sheik Sof Omar used to pray day and night. The cave can also be considered an archaeological site and it is open for archaeologists too.

There are also folktales that the local people believe the cave is mystery where the ancestral cult of Sheik Sof Omar Ahmad, his families and descendants is observed and practiced annually (Aynalem et al., 2015). Even these days, each structure of the cave have been assigned and designated to different ritual practices. According to local informants, annual religious (Islamic) festivals and events are also taken place in the cave shrines and mosques of these underground karstic limestone caverns. Therefore, Sof Omar cave has still provided live service and provide ecclesiastical services to the community in that it has exceptional cultural significance to the spiritual life of the Sufi Muslims.

Therefore, as natural heritage, the cave reveals exceptional physiographic formational and as cultural heritage, it is a typical testimony for human usage of cave shelters for religious purposes and the continuation. Thus, it is crucial to utilize this exceptionally beautiful and inspirational combined value and a double feature of the cave system as a visitor destination.

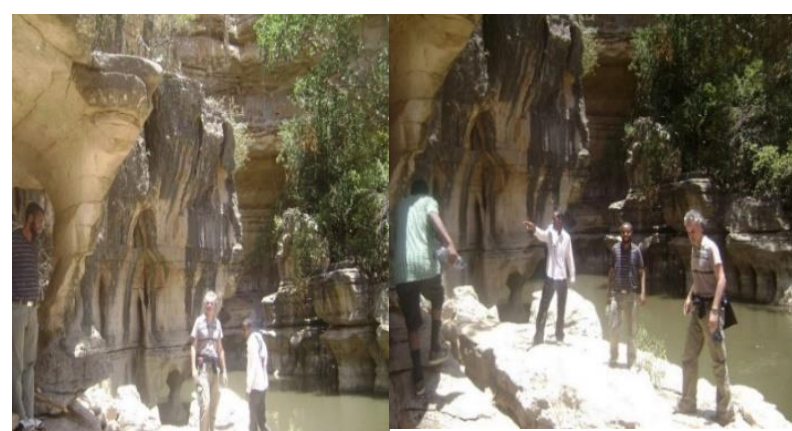

Figure 24: The Researcher during Data collection at Sof Omar Cave: Photo by Data collectors

\section{Southwestern Clusters: Jimma and its Environs}

Southwestern Ethiopia is endowed with rich historical, cultural and natural tourism resources that could attract halal conscious visitors. Especially Jimma area is blessed with numerous cultural, historical and natural halal tourism resources. Among others, the palace of Jimma Aba Jifar, wild coffee forest and unspoiled culture of indigenous peoples are the main visitor attraction in this region (Labouisse et al., 2008). According to tour operator interviewees, recently, researchers and domestic visitors have been flowing towards Jimma to visit the historic site of Aba Jifar and the nearby natural attractions. The number of visitors who show interest to visit the forest coffee of western Ethiopia has been also increasing. Ethiopia is the origin of coffee Arabica and it was in the Southwestern part of Ethiopia that coffee Arabica has been first domesticated (Tucker, 2011). In addition to being the origin of coffee Arabica, one found wild coffee in the area still these days. Hence, the visitor could enjoy both by observing wild coffee forests and by consuming organic coffee. Moreover, most Ethiopian forest resources are concentrated in this region. 


\section{The Palace of Aba Jifar}

The palace of Aba Jifar is one the oldest, largest and surviving traditional wooden architecture palaces in Ethiopia (Aman, 2019). Aba Jifar I is said to have established the most powerful Kingdom Jimma in the 1830s. His relative and successor Aba Jifar II emerged as the most powerful King and built the historic palace of Aba Jifar in the 1880s seven kilometers in the outskirt of Jimma city. It is believed Aba Jifar I chose the area for a strategic purpose. The palace's architectural style and design depict the cultural and historical aspects of the Oromo people. One participant speaks as follows:

The palace of Aba Jifar is believed to have been built by tones of egg, olive tree wood and selected stones. After the lapse of a century, the palace is still intact. These days, however, some parts of the palace are on the brink of falling. The palace is constructed at the strategic site at the hilltop against enemies. The palace of Aba Jifar encompasses the residence of Aba Jifar, the mosque of Aba Jifar and the residence of his grandsons Aba Jobir and Aba Dula.

While visiting Jimma and its vicinity, visitors deepen their expertise and acquire intercultural experiences.

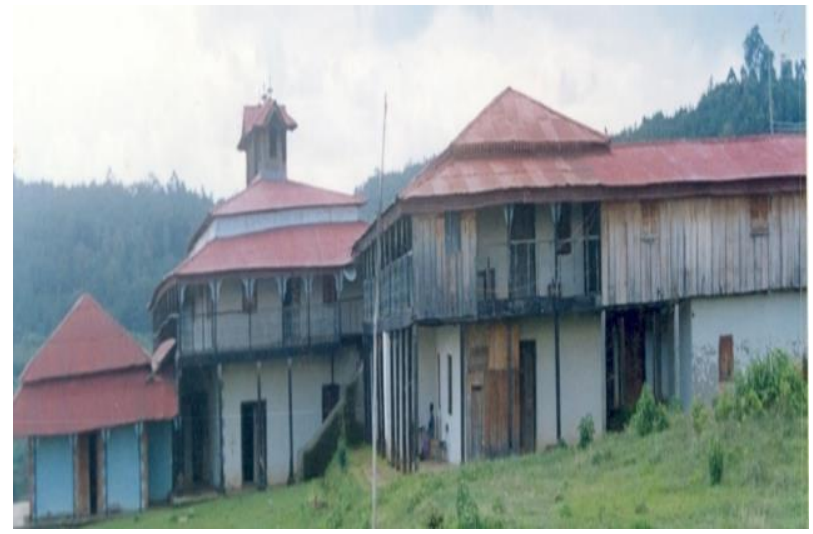

Figure 25: The Palace of Jima Aba Jifar, Source: Adapted from Oromia and Culture Bureau

In addition to having the historic Aba Jifar palace, wild coffee trees and rich forest resources, the Jimma area is endowed with material culture and living heritages.

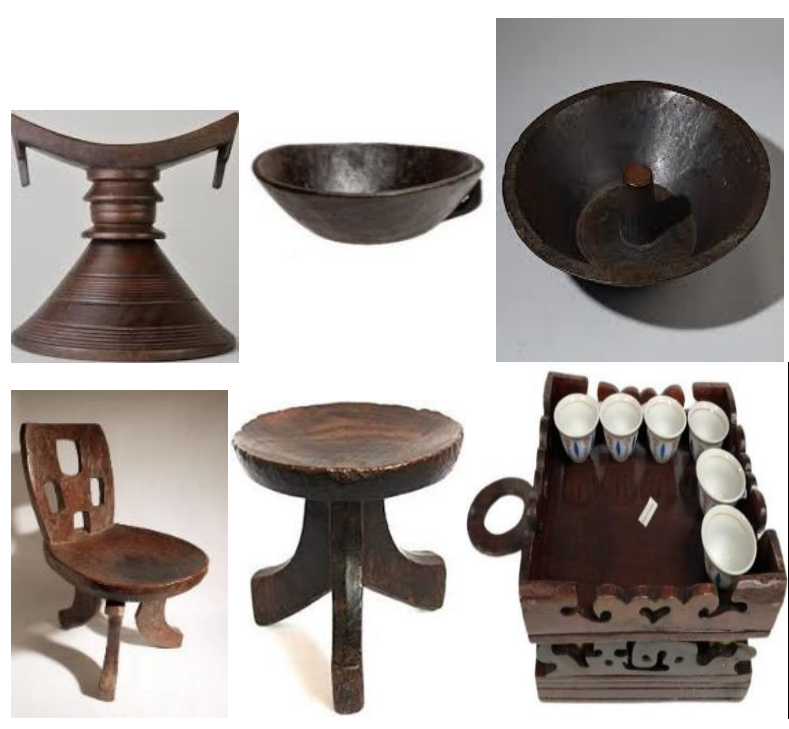

Figure 26: Some Wooden Cultural Tools of Jimma Area

Jimma is branded at the national level not only in coffee but also in wood products such as artifacts, handicrafts, statuettes and furniture. The area is known for its quality cultural wood products and furniture such as beds, tables, stool, bowls, statuette, Ethiopian Coffee table (Rekebot) and woody Cushion (Brkuma). Besides being the birthplace of coffee, Jimma is also known for the coffee ceremony.

\section{Living Intangible Islamic Cultural Heritage Resources}

Ethiopia is rich with varied intangible cultural heritage resources. These Islamic intangible cultural heritages are available in all parts of Ethiopia. Oral traditions, performing arts, social practices, rituals and festive events are major Islamic intangible heritages. Participants from different parts of Ethiopia cite intangible cultural heritage resources. One participant from North Ethiopia Dessie expresses his opinion as follows:

[...] Wollo is a source of the authentic intangible cultural heritages of Islam. In Wollo, one can listen to various traditional Munzuma mainly chanted by Sufi Muslims and watch Sufi dance. These are among the intangible heritages of Ethiopian society, which we do not want to change, could be presented to the visitors as it is, because it represents the local community.

Most of the Islamic intangible heritages are performance arts that could attract visitors who are 
looking for new experiences. A respondent from the Federal Mejlis also stated:

[...] Ethiopian Muslims have much more intangible heritages. These intangible heritages include Islamic songs (Menzuma) and Islamic dance. These heritages are indigenous to Ethiopia and Sufi Muslims still maintain those habits inherited from their ancestors, which could be transformed into various products for tourists.

There are also various Islamic festivals such as Mawlid of Prophet Muhammad (PBUH), Ashura, Eid al Fatir and Eidel Adha where Islamic songs and dances are performed and cultural-religious dressing systems have been displayed. These intangible Islamic heritages may retain halal visitors and spend more if they participate in activities derived from the local culture. Another participant from the federal tourism office suggests the following:

[...] these intangible Islamic heritages could be incorporated into cultural tourism in the area that would, in turn, motivate more halal visitors to visit. Moreover, if halal activities representing local culture and customs were organized, more and more halal visitors will join the tourism sector. Also, the local community could develop many halal tourism-related activities that represent their local culture, and these would provide economic returns for a large segment of the community [...]

\section{Identifying and Mapping Potential Routes of Halal Tourism in Ethiopia}

After inventorying the available attractions, the next step is identifying and mapping appropriate halal tourism routes. Firstly, the concept of tourismroutes was discussed. Then five potential halal tourism routes and their respective nodes of attractions were presented.

Tourism routes are major concerns in tourism development. Tourism route is defined as a network system that connects multiple natural and cultural nodes to provide a diversified tourism product at a time and one route (Chountala et al., 2019). Route planning has become one of the most significant steps in tourism development (Görmüş et al., 2017). Tourism routes help destination managers develop non-promoted sites with high tourism resources into tourists' destinations. Commercial viability is among determinant criteria in proposing the new routes. Tourism routes tie-up several nodes of attractions that would separately not have the power to attract visitors. Therefore, identifying and mapping tourism routes is an important mechanism to develop fragmented attractions in a position to attract tourists. The thematic routes refer to the row up of natural, historical or cultural attractions and make them accessible to different transport forms around a chosen topic or theme (Csapo \& Berki, 2014).

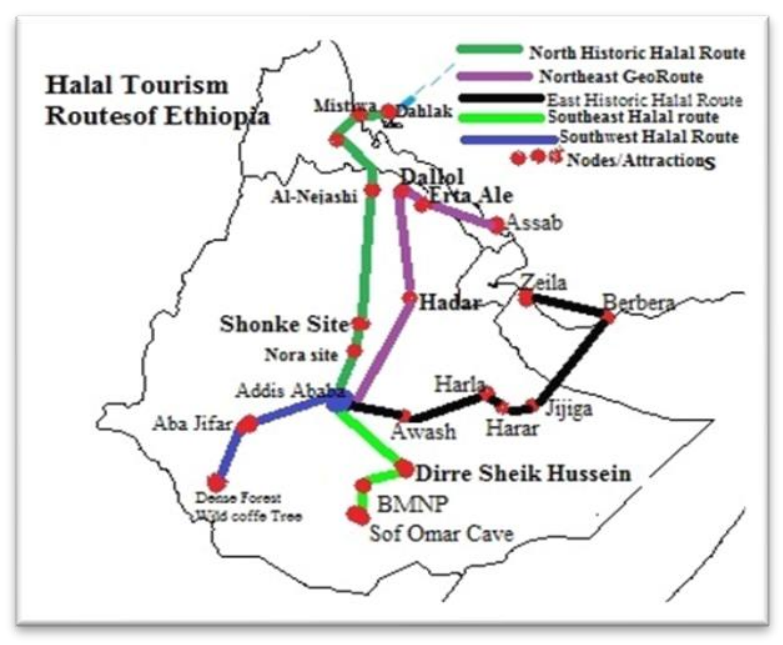

\section{Figure 27: Halal Tourism Routes of Ethiopia: by the Researcher}

The aim of developing halal tourism routes in Ethiopia is to create interrelation and interconnection on diverse and separated visitor attractions by creating historical, economic and cultural linkages between individual attractions. This, in turn, enables visitors enjoying rich experiences and enriches their consumption. Itineraries of a particular visitor route also offer particular advantages in the promotion of tourism as a spatial development strategy, in that demand and expenditure can be diffused to various nodes instead of concentrating on saturated attractions. According to the opinion of tourism experts, tourism routes have long shown to provide the impetus for the development of a range of new attractions and facilities along with the ways. Therefore, first halal visitor attractions were identified and described. Then countrywide distribution attractions become important nodes to propose nationwide halal tourism routes. These routes will reveal not only halal itineraries but also Ethiopia's natural and 
cultural corridors that would fit the interest of halal conscious visitors.

The first tourism route established in Ethiopia was the North Historic Route that includes historic sites of BahirDar, Gonder, Lalibela and Axum (Sisay, 2009; Tafesse, 2016). Established in the 1960s, this route has attracted the vast majority of the country's visitors to date. This route, however, did not include Islamic heritages. Even iconic Islamic heritages such as the historic site of al-Nejashi were not included in this route. Another example of a successful commercial route is the south ethnographic route in which iconic Islamic heritages such as the palace of Aba Jifar were not considered. The current proposal of halal tourism routes involves resourceful but historically disadvantaged communities in tourism route development. The role of halal routes to develop halal tourism in Ethiopia unanimously shared among all participants of tourism experts. Forming routes in collaboration with relevant local stakeholders make economic sense from a marketing, networking and economic perspective.

The proposal of all routes was based on the principle of tourism development that tourism development could be sustainable only when it involves the local communities and consider the very interest of the indigenous people (Briedenhann \& Wickens, 2004). Accordingly, the local communities' representatives, investors and tourism experts were consulted during the route proposing process. Tourism theories agreed that tourism developments are unlikely to succeed if they are not adopting a "community-based approach" in which local communities are given the opportunity to be decision-makers in the courses and the ends of the project. Unfortunately, impracticable political promises of employment opportunities have made some people doubtful to engage in such a project. There were also widespread feelings of inequality, fear, distrust and resentment that affect successful community participation. Some people perceived such kind of development initiatives as exploitative and political. Conflict of interest often occurs between the indigenous community and the industry actors. During the development of new tourism, it is obvious that mistrust between various groups is inevitable since the potential benefit to one sector of the community might marginalize others.
Finally, by using the "thematic route" design and geographical actuation zone, five main halal tourism routes were identified and proposed. These are the North historic halal tourism route (AlNejashi historic route), Northwest halal geo-route, Eastern historic halal tourism route (Harar historic route), the Southeast Halal eco-route and Southwest halal route (Aba Jifar route). The viability, feasibility and long-term sustainability of these routes were well considered.

\section{The North Historic Halal Tourism Route (Al- Nejashi Historic Route)}

The North historic halal tourism route also called the Al-Nejashi Historic Route is a border-crossing route that runs from Addis Ababa, Ethiopia towards the north as far as Massawa and Dahlak Islands of Eritrea. This route transcends not only international borders but also geographical diversity. It connects historic sites and Islamic heritages in Ethiopia and Eritrea. The Al-Nejash route provides a unique tourism experience that links Ethiopia's Islamic heritage to Eritrea's Islamic heritage and coastal areas. The route starts from Addis Ababa and heads through the Islamic archaeological sites of North Showa and literary landscapes of Wollo to Tigray open historic sites of Al-Nejashi, before heading north to the tourism sites of Eritrea, Massawa and the Dahlak archipelagoes. This route will transcend to Saudi Arabia by tracing the footprint of the Sahabas (companion of Prophet Mohammed) who conduct the first Hijra towards Habesha in 615.

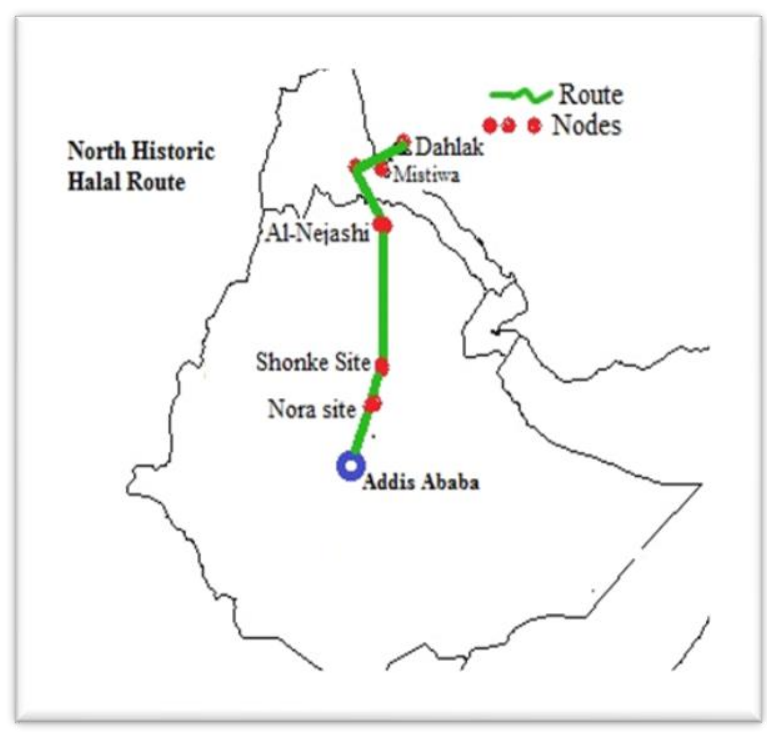

Figure 28: North Historic Halal Tourism Routes: By the Researcher 
The Al-Nejashi historic route covers most of the northern part of Ethiopia. The Islamic archaeological and heritage sites of the Showa particularly Ifat Sultanate in North Showa, heritages buildings of Shonke residential complex and Mosque in Wollo and the Historic Mosque and religious sites of Al-Nejashi in Tigrai Wukro as major nodes of this route. Secular sites such as the battlefield of Adwa, where Ethiopians defeated Italian in 1896 and breathtaking landscapes of Northern Ethiopia will be supplementary assets of this route. Adwa is a historic place where the black defeated the white imperialist force for the first time in history.

Therefore, halal conscious visitors will enjoy visiting this historic battlefield. The Al-Nejashi Historic Route consists of overlapping nodes and therefore has more capacity to capture the visitors' attention. This route will have a comparative advantage over others for having overlapping Islamic heritages throughout the way and the availability of the north historic route in the same direction. These factors could increase the values of this route. The promotion of the proposed route is an integral part of route formation. Otherwise, visitors may hardly aware of this route.

\section{The Northwest Halal Geo-Route (The Danakil Geo-Route)}

As discussed earlier, Northeast Ethiopia mainly the Afar region is rich in geological and archaeological visitor attractions. After having studied the attractions, it is also necessary to assess how to interconnect these sites and make them accessible to visitors. Northwest halal route or the Danakil GeoRoute is a border-crossing route that runs northeastwards from Addis Ababa, Ethiopia as far as Assab, the port of Eritrea. This route connects tourism routes of the Afar regional state mainly geological and archaeological sites such as Hadar archaeological sites (where Lucy was discovered), the Erta Ale active volcano and Dallol depression, and transcends international borders towards Assab port. It connects visitor attractions of the Afar region with Addis Ababa and Assab. The Danakil Geo-route provides a unique tourism experience mainly geological, geomorphological and archaeological sites. The route starts at Addis Ababa and passes through the lower Awash_Hadar, Ertale and Dallol before heading north to the tourism sites of Eritrea, Assab port.

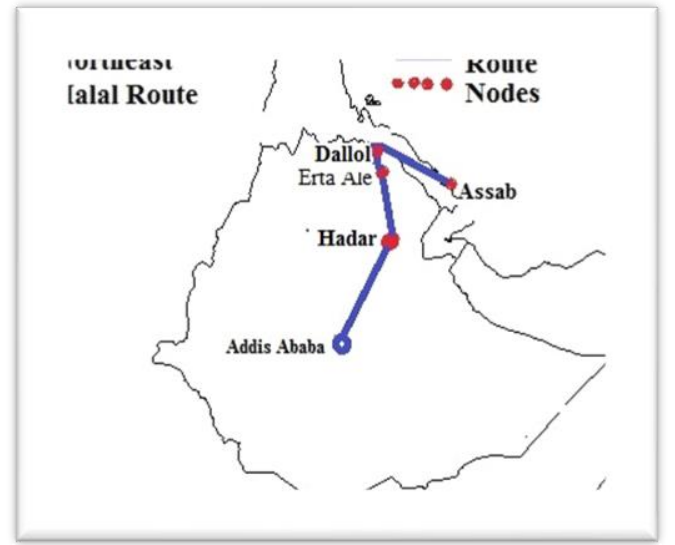

\section{Figure 29: North East Halal Route: by the} Researcher

\section{The East Historic Halal Tourism Route}

In Eastern Ethiopia, there was a legendary longdistance trade route connected East Ethiopia with the central Ethiopia. This historic long-distance route has realized the economic, cultural, political and religious interactions between Eastern Ethiopia and other parts of Ethiopia and the port cities of the horn of Africa. The present proposed route will more or less follow the pattern of this historic route. The proposed Eastern Historic Route or the Harar historic route will run from Addis Ababa eastwards to the historic city of Harar with a probable extension as far as Zeila and Berbera. This route will connect several nodes such as Awash national park, archaeological sites of Harlaa, the walled historic city of Harar and leads to the ports of Berbera and Zeila through Jigjiga. Just like other routes, the visitation will be started from Addis Ababa and continue to pass through the following nodes of destinations.

Bishoftu and its volcanic lakes: the visitors will enjoy observing some of the unique birdlife, experimented ornithologist attractions. The Awash Park: here in addition to the park, the visitor will enjoy with cultural lifestyles of Kereyu pastorals. Harlaa is an abandoned Islamic city located between Harar and Dire Dawa. The visitor will spend a good time at Harlaa and spend the night at Dire Dawa. Dire Dawa the so-called "the New Harar" was established in 1902 following the construction Djibouti-Addis Ababa railway, and now becomes an important cosmopolitan city of Eastern Ethiopia. 


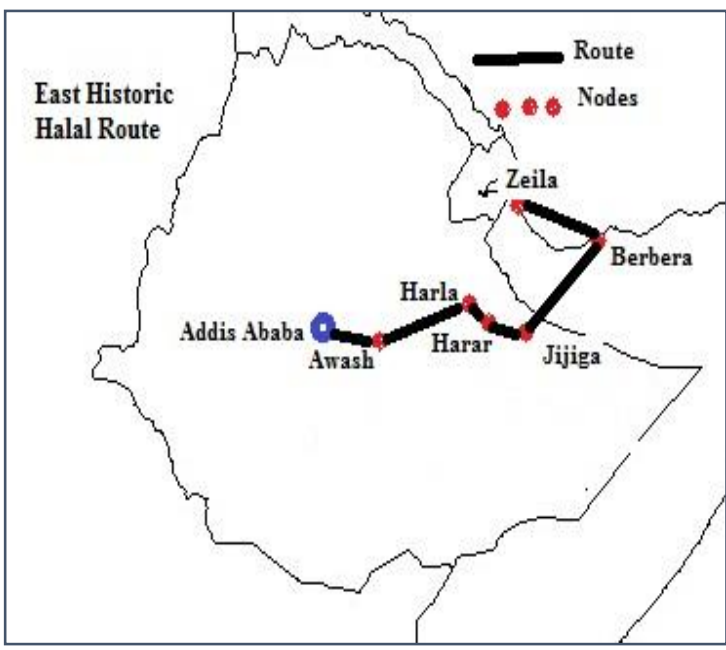

Figure 30: The East Historic Halal Route: By the Researcher

Harar, the sub-developed destination with some amenities, and rich historical and cultural attractions in Eastern Ethiopia will be a major node in this route. As discussed earlier in this paper, the walled city of Harar serves as the main attraction for visitors visiting Eastern Ethiopia. Babile and Gursum (the Dakhata Valley and the Kundudo Mountain) will be important nodes of the new route. As the head of Babile culture and tourism bureau stated that:

[...] apart from the walled city of Harar and other many attractions, new visitor attractions being discovered in East Ethiopia. The famous Abyssinian Elephants sanctuary in Babile is another quality of this area. Due to these qualities, the construction of a Halal lodge either in Babile or in Gursum has been strongly recommended.

This route will transcend towards Hargeisa, Zeila and Berbera of Somalia. In such a way, this route will be extended as far sea outlet so that the visitor may come to this route by ship directly from abroad and will be able to visit from frontier to interior.

\section{The Southeast Halal Route (Bale Eco-Route)}

The Southeast Halal Eco-Routes runs from Addis Ababa towards southeastern parts of Ethiopia, Bale zone. In these routes, there are three major nodes, namely, the Bale mountains national parks, Dire Sheik Hussein historical and religious sites and Sof Omar cave system. However, visitors could enjoy visiting other attractions in the area.

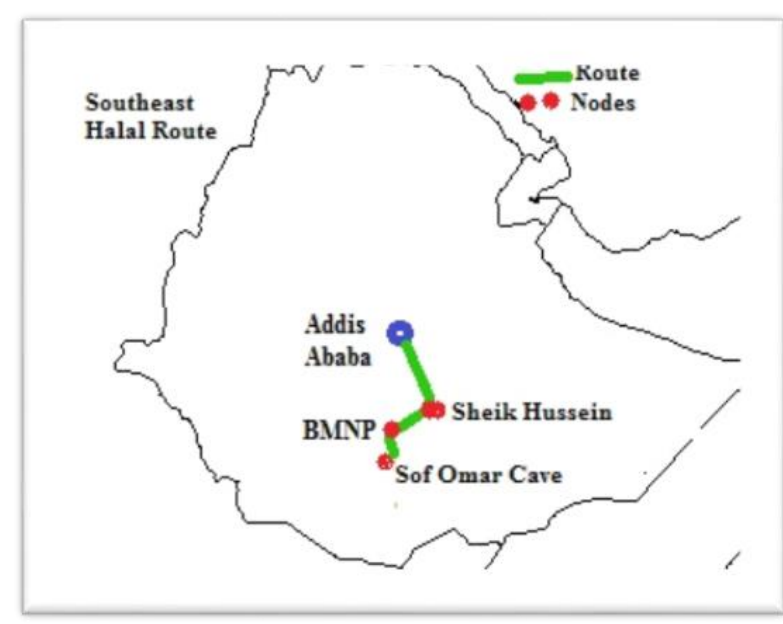

Figure 31: Southeast Halal Route: by the Researcher

\section{The Southwest Halal Tourism Route (The Aba Jifar Eco-Route)}

This route runs from Addis Ababa towards Southwestern Ethiopia. The Palace of Aba Jifar and wild Coffee forests are the major attractions of this route. This route will include various natural resources and forests of Southwestern Ethiopia. It will also runs as far as Grand Ethiopian Renaissance Dam (GERD).

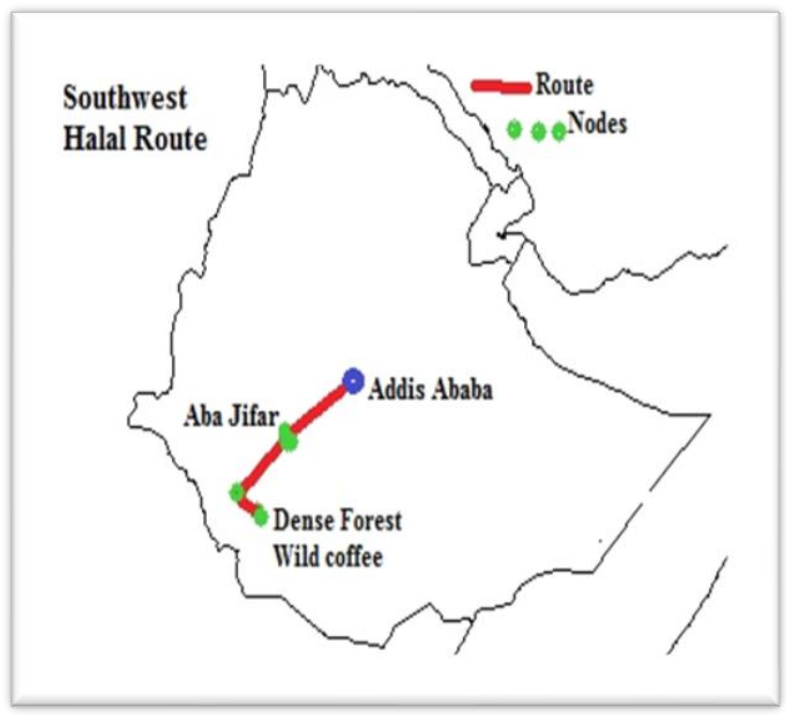

Figure 32: The Southwest Halal Route: by the Researcher

Most of Ethiopia's forest resources are found in this part of the country. When fully utilized, this route will be connected with Senkelle Swayne's Hartebeest Sanctuary, Oromo National park, Mago national park and Gambella national park. 


\section{Concluding Remarks}

This paper discussed the availability and viability of halal sites and routes in Ethiopia. Sites and routes are the core elements of tourism development. Based on geographical zones and locations, halal visitor attractions were categorized into five clusters namely the north cluster, the northeast cluster, the eastern cluster, the southeast cluster and the southwestern cluster. Each cluster comprises important natural, historical, cultural archaeological and geological attractions. The locations of these attractions were identified by using the Global Positioning System (GPS) and Geographic Information System (GIS) and they were plotted on a map. Data obtained from fieldworks and google earth were employed to identify the geographical location of these attractions. After having identified visitor attractions that have a greater potential to attract halal conscious visitors, viable halal tourism routes have been identified and proposed.

Generally, five major halal tourism routes were identified and proposed for further development. These routes are the north historic halal route, the northwest halal Geo-route, eastern halal route, southeast halal eco-route and southwest halal ecoroute. The North historic halal route (Al-Nejashi historic route) interconnects great archaeological and historical sites of Ethiopia, even Eritrea. This route more or less follows the footprint of the pioneer Sahabas who immigrated towards Habesha during the first Hijra in 615. Hence, this route will transcend as far as the Gulf States such as Saudi Arabia. This route may very fit for religious and history-lover visitors. The Northeast halal geo-route will mainly interconnect the geological attractions Afar region. This route could be very attractive and conducive for nature-lover visitors and adventurers. The Eastern historic halal route comprises historic cities of Islamic sultanates and it follows the trend of the historic long-distance trade. The southeast halal eco-route connects three major attractions of the Bale area namely, Bale mountains national park, Sof Omar Cave System and Dire Sheik Hussein Religious and Historic site. The southwest halal route leads towards Palace Jimma Aba Jifar and the nature-based attractions of Southwestern Ethiopia. This route will take environmentalist, eco-friendly and nature-lover visitors to the point of their suit. These routes and their respective nodes were plotted on a map by using GIS technology.
The Ethiopian government and other stakeholders should develop and promote tourism resources and halal routes. The study identifies marginalized and the most ignored tourism resources of the country. Most of these attractions are on brink of destruction and extinction. Hence, the government, the local community and other stakeholders should work together to maintain these heritages. Facilities and ancillaries should be set up and halal services should be offered at these sites along the proposed halal routes. These attractions and halal routes should be branded, promoted and introduced to mainly halal customers.

\section{REFERENCES}

Ahmed, H. (2004). Shaykh Jawhar b. Haydar b. 'Alī: A mystic and scholar of Shonkē, southeast Wallo, Ethiopia. Annales d'Ethiopie, 20(1), 47-56. https://doi.org/10.3406/ethio.2004.1069

Ahmed, W. M. (2015). History of Harar and the Hararis (Issue October). HARARI PEOPLE REGIONAL STATE CULTURE, HERITAGE AND TOURISM BUREAU October.

Aman, A. (2019). Identification and Documentation of Potential Tourism Resources : It 's Management Practice in Focus in Jimma Town and its Vicinity, Southwestern Ethiopia. J Tourism Hospit, 1-8. https://doi.org/10.35248/2167-0269.19.8.418

Asante, B. (2009). Merging past and present : Local level conservation of material culture in the museums of Harar , Ethiopia. Nilo-Ethiopian Studies 13: 1-16, 13, 1-16.

Aynalem, S., Akele, B., Alemayehu, H. ., \& Molla, G. (2015). Assessment and Identification of the Tourism Resources of Bale Zone, Ethiopia. Journal of Tourism \& Hospitality, 04(04). https://doi.org/10.4172/2167-0269.1000176

Bank, W. (2006). Ethiopia: Towards a Strategy for Pro-Poor Tourism Development (Issue June).

Bayih, B. E., \& Tola, M. W. (2017). Practices and challenges of promoting major tourism destinations of Bale Zone for Sustainable Tourism Development in Ethiopia. African Journal of Hospitality, Tourism and Leisure, 6(2).

Briedenhann, J., \& Wickens, E. (2004). Tourism routes as a tool for the economic development of rural areas-vibrant hope or impossible dream? Tourism Management, 25(1), 71-79. https://doi.org/10.1016/S0261-5177(03)00063-3 Cavalazzi, B., Barbieri, R., Gómez, F., Capaccioni, 
B., Olsson-Francis, K., Pondrelli, M., Rossi, A. P., Hickman-Lewis, K., Agangi, A., Gasparotto, G., Glamoclija, M., Ori, G. G., Rodriguez, N., \& Hagos, M. (2019). The Dallol Geothermal Area, Northern Afar (Ethiopia) - An Exceptional Planetary Field Analog on Earth. Astrobiology, 19(4), 553-578. https://doi.org/10.1089/ast.2018.1926

Chountala, V., Chountalas, P., Magoutas, A., \& Mavragani, E. (2019). The cultural route of Hercules: Mapping the tourist's perspective. International Journal of Tourism Policy, 9(2), 131154. https://doi.org/10.1504/IJTP.2019.102638

Cieśluk, K., Karasiewicz, M., \& Preisner, Z. (2014). Geotouristic attractions of the Danakil Depression. Geotourism/Geoturystyka, $1((36)), \quad 33$. https://doi.org/10.7494/geotour.2014.36.33

Csapo, J., \& Berki, M. (2014). Existing and future tourism potential and the geographical basis of thematic routes in south Transdanubia, Hungary To cite this version: HAL Id: halshs-00516130.

Erlich, H. (1994). Ethiopia and the Middle East. Lynne Rienner Published Ltd.

Erlich, H. (2009). Islam , Christianity , Judaism , and Ethiopia: The Messages of Religions. The Nehemia Levtzion Center for Islamic Studies The, 1-19.

Eyassu, A. W., Chekole, Y. A., \& Tadesse, G. T. (2019). Tourism development potentials and challenges in Shonke Village, Ethiopia. African Journal of Hospitality, Tourism and Leisure, 8(5), 1-16.

Fauvelle-Aymar, F.-X., Bruxelles, L., Amélie Chekroun, R. M., Olivier Onézime, A. W., Deresse Ayenatchew, H. Z., Hirsch, B., \& Mohamed, A. (2006). A Topographic Survey and Some Soundings at Nora, an Ancient Muslim Town of Ethiopia. Journal of Ethiopian Studies, 39(1/2), 111.

Fyall, A., Garrod, B., \& Leask, A. (2012). Managing visitor attractions: New directions. Taylor and Francis. https://doi.org/10.4324/9780080496368

GÖRMÜŞ, S., ATMIŞ, E., GÜNŞEN, H. B., ÖZKAZANÇ, N. K., \& ARTAR, M. (2017). The Importance of Mapping Natural and Cultural Routes in Rural Tourism: Bartın Case. Research Journal of
Agricultural Sciences, 10(1), 32-38. www.nobel.gen.tr

Hussien, A. (2001). Islam in the Ninetenth-Cuntry, Wallo, Ethiopia: Revival, Reform and Reaction. In Social, Cultural and Political Studies of The Middle East and Ethiopia. Brill.

Insoll, T. (2017). First footsteps in the archaeology of harar, ethiopia. Journal of Islamic Archaeology, 4(2), 189-215. https://doi.org/10.1558/jia.35273

Insoll, T., Khalaf, N., Maclean, R., \& Zerihun, D. (2017). Archaeological survey and excavations, Harlaa, Dire Dawa, Ethiopia January-February 2017. A preliminary fieldwork report. Nyame Akuma, 2017-June(87), 32-38.

Khalaf, N., \& Insoll, T. (2019). Monitoring Islamic Archaeological Landscapes in Ethiopia Using Open Source Satellite Imagery. Journal of Field Archaeology, 44(6), 401-419. https://doi.org/10.1080/00934690.2019.1629256

Labouisse, J. P., Bellachew, B., Kotecha, S., \& Bertrand, B. (2008). Current status of coffee (Coffea arabica L.) genetic resources in Ethiopia: Implications for conservation. Genetic Resources and Crop Evolution, 55(7), 1079-1093. https://doi.org/10.1007/s10722-008-9361-7

Pradines, S. (2011). the Medieval Mosques of Nora Islamic Architecture in Ethiopia. June.

Semu, K. T. (2016). Dynamics of the Cult of Sheik Hussein of Bale, Ethiopia: Its Course and Curse of the Extremists, a Historical Perspective. Ethiopian Journal of the Social Sciences and Humanities, 12(1), 63-101-101.

Sisay, A. (2009). Historical Development of Travel and Tourism in Ethiopia (Kuraz (ed.)).

Tafesse, A. (2016). The Historic Route in Ethiopian Tourism Development. African Journal of Hospitality, Tourism and Leisure Volume, 5(2), 013.

Tola, S. (2009). The Conservation of Dirre Sheikh Hussein Heritage Site.

Trimingham, J. S. (1952). Islam in Ethiopia. Oxford University Press.

Tucker, C. M. (2011). Coffee Culture: Local Experiences, Global Connections. Routledge Tyalor and Francis Group. 


\section{Ethical approval}

This study is among the studies that do not require ethics committee approval due to not fall within the scope of research that requires one-to-one data collection from the participants and the data are obtained as secondary data.

\section{Contribution rate of researchers}

The authors contributed equally to the study.

Conflict of interest

There is no potential conflict of interest in this study. 